\title{
Gerinces fosszíliák és kutatásuk a Kárpát-medencében
}

\author{
Ezt a munkát 70. születésnapja alkalmából Prof. Dr. Kordos \\ Lászlónak ajánljuk, tanárunknak, kollégánknak, aki nélkül \\ a hazai gerinces paleontológiai kutatás nem tartana itt.
}

\author{
ŐsI Attila, MÉSZÁROS Lukács
}

Eötvös Loránd Tudományegyetem, Őslénytani Tanszék, Pázmány Péter sétány 1/C, Budapest 1117, Hungary hungaros@gmail.com

\section{Vertebrate fossils and associated research in the Carpathian Basin}

Abstract

The richest vertebrate sites in the Carpathian Basin are mainly Neogene and Pleistocene. However, there are some Mesozoic localities that have been researched for decades and these are also of great international interest. The highly sporadic Palaeozoic finds are mostly based on microfossils (conodonts) and some Carboniferous-Perm footprints, the former being biostratigraphically significant and the latter paleobiogeographically important. In addition to some notable scattered finds (Placochelys placodonta) from the Triassic period, old and new localities in Bihar and Villány provided diverse, predominantly marine vertebrate faunas. These have added considerably to our knowledge on shelf faunas of the southern Eurasian margin

The Jurassic vertebrate record is composed of mainly isolated finds (e.g. the Magyarosuchus marine crocodile) or tracksites (Komlosaurus). The oldest fauna of the Cretaceous period is the archosaurian assemblage which was trapped in the Berriasianaged bauxite of Bihar. This was followed in time by recently discovered fish and reptile bones and teeth from the Albian Alsópere Bauxite. The Santonian-aged Iharkút and Ajka vertebrate sites, discovered 20 years ago, provided a unique and diverse assemblage that fills a significant gap in the Late Cretaceous European record. The Maastrichtian Transylvanian localities, discovered 125 years ago, provided a highly unique island fauna including huge pterosaurs, dwarf sauropods and dome-headed multituberculate mammals. These Late Cretaceous assemblages are now among the dominant continental vertebrate records worldwide and offer a great insight into the insular faunal evolution of the European archipelago.

From the Hungarian Palaeogene mainly sporadic fossil sites with aquatic vertebrates were discovered and only a few of them yielded richer terrestrial faunas (e.g. Máriahalom, Bodajk).

The 17-million-year-old Ipolytarnóc footprints, conserved by a volcanic eruption, are the best known of the Lower Miocene fossils. The famous giant petrified pine trunk and a rich shark tooth assemblage have also been preserved in this site. Many remains of Badenian, Sarmatian and later (Pannonian) sea cows, seals and cetaceans were collected from the Mecsek sand layers (e.g. Danitzpuszta sand mine). Several significant sites from the terrestrial Middle Miocene have been excavated over the last three decades (Sámsonháza, Mátraszőlős, Hasznos, Tasád/Tăşad). Their small mammal faunas were preserved by swamps and lacustrine accumulations. They are indicators of a warm and humid subtropical climate.

The fossil ape Rudapithecus hungaricus, which is the best known palaeontological discovery to have occurred in Hungary, is an element of the rich late Miocene (10 million years old) subtropical ecosystem of Rudabánya. A similar fossil community was discovered in the covering layer of a gypsum mine in Alsótelekes. Gyepüfüzes (Kohfidisch), Götzendorf, Sümeg, Csákvár, Bérbaltavár, Tardosbánya, Polgárdi and other rich sites demonstrate the environmental transformation which took place during the Pannonian Age. It was then that the rich, subtropical forests disappeared and were replaced by wooded and then grassy savannas and finally sporadic desert areas. The alginate layers of the Pula locality were deposited in a Pliocene volcanic crater lake. They yielded many well-preserved leaf and arthropod fossils, as well as fish and mammalian remains. The findings from Ajnácskő (Hajnáčka) were preserved by a volcanic eruption, while the fauna of Ivánháza was discovered in the sediments of karst fissures. The karst fillings of Csarnóta, Beremend and Osztramos show the faunal changes at the end of the Pliocene and the beginning of the Lower Pleistocene. Exceptionally rich Quaternary assemblages were found near Gombaszög (Gombasek) in the Hungarian Highlands and from Betfia in Transylvania. More than 100 localities have been described from the Pleistocene of Hungary and at least 150 different faunas were found in them. Most of these are from fillings of karst cavities, but there are also fluviatile and aeolian sediments. Many findings of ancient humans have also been found in several localities (e.g. Vértesszőlős: Homo heidelbergensis, Subalyuk: Homo sapiens neanderthalensis, Istállóskő: Homo sapiens sapiens). Recently, detailed multidisciplinary investigations have been carried out with respect to some of these faunas (e.g. Somssich Hill, Süttó, Tokod, and Vaskapu Cave) by research groups comprised of different specialists. The macro- and microfaunas of these sites appropriately reflect Quaternary climatic changes. 


\section{Összefoglalás}

A Kárpát-medence leggazdagabb gerinces lelőhelyei főként neogén és pleisztocén korúak, de akad köztük néhány mezozoikumi is, mely évtizedek óta kutatott és nagy nemzetközi érdeklődésre tart számot. Az igen szórványos paleozoikumi leletanyag leginkább mikrofosszíliákon (Conodonták) és néhány karbon-perm lábnyomon alapul, mely előbbiek biosztratigráfiai, utóbbiak ősállatföldrajzi hozadéka jelentős. Amíg a triász időszakból néhány számottevő szórványlelet (Placochelys placodonta) mellett a bihari és villányi lelőhelyek szolgáltattak diverz, döntően tengeri gerinces faunát, jura gerinces leleteink a hettangi korú Komlosaurus lábnyomokon túl tengeri szórványleletek (pl. Magyarosuchus tengeri krokodil). A kréta időszak legidősebb faunáját a bihari berriázi bauxitban csapdázódott Archosauria-csontok jelentik, melyeket időben az Alsóperei Bauxitból nemrégiben felfedezett hal- és hüllőcsontok, illetve -fogak követnek. A 125 éve feltárt erdélyi és 20 éve felfedezett santoni korú iharkúti és ajkai ősgerinces lelőhelyek sokezres leletanyagukkal és diverz faunájukkal mára Európa meghatározó, paleobiológiai szempontból igazi csemegéket szolgáltató kontinentális gerinces együttesei.

Néhány gazdagabb fauna (pl. Máriahalom, Bodajk) kivételével a paleogénből csak szórványlelőhelyek maradtak fent a Kárpát-medencében, amelyek elsősorban vízi gerinceseket szolgáltattak. Az alsó-miocénből az ipolytarnóci ôslábnyomos lelőhely a legismertebb, ahonnan a vulkáni hamuszórás által konzervált több ezer ôsgerinces lábnyomon kívül gazdag cápafogegyüttes is előkerült. A mecseki homokrétegekből (pl. danitzpusztai homokbánya) badeni, szarmata és későbbi (pannóniai) tengeri tehenek, fókák és cetek maradványait gyújtötték. A szárazföldi középső-miocénből az utóbbi három évtizedben több jelentős lelőhelyet tártak fel (pl. Sámsonháza, Mátraszőlős, Hasznos, Tasád/Tăşad), amelyek meleg és nedves, szubtrópusi klímát jelző kisemlősfaunáját mocsári, tavi vagy lagúnafelhalmozódások őrizték meg. A híres Rudapithecus hungaricus főemlős, amely hazánk nemzetközileg legismertebb lelete, a gazdag rudabányai későmiocén szubtrópusi életközösség része volt. Hasonló korú és összetételú fosszilis anyagot gyưjtöttek az alsótelekesi gipszbánya fedőjének mocsári-tavi-folyóvízi rétegiből is. Gyepüfüzes (Kohfidisch), Götzendorf, Sümeg, Csákvár, Bérbaltavár, Tardosbánya, Polgárdi, valamint még sok gazdag pannon korú lelőhelyünk azt a környezeti átalakulást tükrözi, melynek során eltűntek a dús, szubtrópusi erdők, és helyüket ligetes, majd füves szavannák, helyenként sivatagos területek foglalták el. A pulai alginitbánya egy pliocén krátertó üledékeit tárta fel, benne többek között halak és emlősök maradványaival. Az ajnácskői(Hajnáčka) leleteket is vulkáni folyamatok őrizték meg, míg a kis- és nagyemlősökben egyaránt gazdag ivánházai faunát karsztüreg-kitöltésekben fedezték fel. A csarnótai, beremendi és osztramosi karsztkitöltések a pliocén végi és az alsó-pleisztocén eleji változásokat tárják elénk. Felvidékről Gombaszög (Gombasek), Erdélyből Betfia szolgáltatott igen gazdag negyedidőszaki leletegyütteseket. A magyarországi pleisztocénből több mint 100 lelőhelyet és ezekről legalább 150 különböző faunát ismerünk, főként karsztüregek kitöltéseiből, kis részben folyóvízi vagy eolikus üledékekből. Az ôsi emberfélék jelentős leletei is előkerültek számos helyről (pl. Vértesszőlős: Homo heidelbergensis, Subalyuk: Homo sapiens neanderthalensis, Istállóskő: Homo sapiens sapiens). Több kvarter lelőhelyen (pl. Somssich-hegy, Süttő, Tokod, Vaskapu-barlang) az utóbbi években is sokoldalú vizsgálatok folytak. Ezek makro- és mikrofaunája egyaránt jól tükrözi a negyedidőszaki klímaváltozásokat.

Tárgyszavak: gerincesek, paleozoikum, mezozoikum, kainozoikum, Magyarország, Kárpát-medence

\section{Bevezetés}

A gerinces ősmaradványok kutatása a Kárpát-medencében régi időkre és nagy múltra tekint vissza. Az első gerinces fosszíliák felfedezése (pl. pleisztocén nagyemlősök csontjai) bizonyára több évszázaddal ezelőtt megtörtént, és az első leletek leírása már a 19. század elején megkezdődött (FôZY \& SZENTE 2007). A 19. század második és a 20. század első felében már szisztematikus ásatások, feltárások zajlottak, melyek nagyban hozzájárultak leginkább a neogén gerinces faunáinak jobb megismeréséhez (lásd pl. KADIĆ 1915; Kadić \& KoRMOS 1934; Kadić \& MotTL 1944; Kormos 1925, 1937; Kretzor 1941; és lásd még az irodalmakat KRETZOI 1956b; JÁNOSSY 1979; KoRdos 1992 és PAZONYI 2009-es munkáiban).

A Kárpát-medencében felszínre bukkanó üledékes kőzetek legnagyobb hányada fiatal neogén korú, így a gerinces ősmaradványok többsége (pl. hasadékkitöltések, barlangok csontbreccsái) is ebből az időből származik. Idősebb, paleogén vagy mezozoikumi rétegsorokból már jóval ritkábban kerültek elő gerinces állatok maradványai; ez utóbbiak vagy szórványleletek, vagy kivételes, tudatosan keresett és szisztematikusan feltárt lelőhelyek.

Ebben az összefoglaló munkában a teljesség igénye nél- kül összegyújtjük a Kárpát-medence legfontosabb gerinces ősmaradvány lelőhelyeit és dokumentált leletanyagait. Röviden tárgyaljuk e fosszíliák hazai és nemzetközi jelentőségét, és kitekintést adunk arra vonatkozóan, hogy hol és milyen korú kőzetrétegek lehetnek még potenciálisak a gerinces paleontológiai kutatások szempontjából a Kárpát-medencében.

\section{Leletanyagok kor szerint}

\section{Paleozoikum}

A Kárpát-medencében igen kis területen fordulnak elő paleozoikumi kőzetek a felszínen, és amelyek elérhetők, azok sok esetben metamorfizálódottak, vagy alig ismert belőlük fosszília. Ezek a kőzetek szinte kivétel nélkül tengeri környezetben képződtek, így szárazföldi gerincesek maradványai, néhány lábnyomtól eltekintve, nem ismertek. Amíg Nyugat- és Észak-Európa vagy Oroszország területén nagy kiterjedésben bukkannak a felszínre késô paleozoikumi szárazföldi, folyóvízi vagy partközeli üledékes rétegsorok, melyek gazdag kétéltú (SCHOCH 2014) és korai hüllő leletanyagokat (SUES 2019) szolgáltattak, a Kárpát-medence területén ilyen környezetekben képződött kőzetek csak 
sporadikusan és nagy mélységekben fordulnak elö, melyekrôl a legjobb esetben egy-egy mélyfúrás révén értesültünk.

A Dunántúli-középhegységi, mecseki és észak-magyarországi paleozoikum szilur, devon és karbon rétegeiből Conodonták, azaz állkapocs nélküli halak kalcium-foszfátos fogképletei kerültek elő, melyek rendkívül fontosak a sokszor metamorfizált kőzetek korának meghatározásában (Oravecz 1964, LelKesné-Felvári et al. 1984, KoCZUR 1984, KocZUR \& MocK 1977, FülöP 1990).

A magasabbrendú halakat izolált fogak (Acrodus), illetve kúpos, gumós fogakat viselő foglemezek képviselik (FENNINGER \& NIEVOLL 1983), melyek a Nagyvisnyó határában található Mihalovits-kőfejtő perm időszaki rétegeiből is ismertek.

Tetrapoda, tehát négylábú gerincesek (paleozoikum esetén kétéltűek és hüllôk értendők ide) testfosszíliái gyakorlatilag ismeretlenek ezekből az időkből. Mindösszesen néhány kétéltú lábnyom (Batrachichnius, Platytherium) került elő a Villányi-hegység északi előterében mélyített Turony-1 mélyfúrás felsô-karbon rétegeiből (BARABÁSNÉ STUHL 1975). Továbbá ismert még egy közel hat centiméteres lábnyom a Balaton-felvidéki felső-perm vörös homokkó rétegeiből (MAJOROS 1964, KASZAP 1968, VoigT 2005). Bár a lábnyom leginkább a kora-perm Ichniotherium nyomokra emlékeztet, melyek feltehetően korai növényevő, diadectid hüllőktől származnak, MARCHETTI et al. (2017) a hazai lábnyomot illetően a Tetrapoda indet. besorolásnál nem megy tovább. Emellett KORDOS (2018) említ változatos lábnyomegyüttest e homokkő Balaton-parton hullámtörésre használt blokkjaiból.

\section{Triász}

Paleozoikumi előfutáraikhoz képest a triász időszaki kőzetek már jóval nagyobb kiterjedésben fordulnak elő középhegységeink területén. Döntő többségük tengeri környezetben képződött, így szárazföldi gerincesek leletei szinte teljesen hiányoznak. A Kárpát-medence területén sokáig csak néhány szórványlelet árulkodott a gerincesek triász időszaki előfordulásáról. Ezek közül a leghíresebb a veszprémi Jeruzsálem-hegyről előkerült Placochelys placodonta késő-triász leletanyaga, melyet az akkoriban ott található kőfejtők munkásai és LACZKó Dezsô paptanár fedeztek fel 1901 áprilisában (BoNTó 2019). Az első felfedezés során egy erôsen cementált, meszes kőzettömbból került elô a holotípus leletanyaga, többek között egy teljes koponyával, alsó állkapoccsal és postcranialis elemekkel, köztük vastag, kúpokkal erôsen díszített páncélzat darabjaival (JAEKEL 1902, 1907). SEMSEY Andor, a kor és talán minden idők legnagyobb magyar Geo-mecénása is támogatta a további kutatásokat, melynek eredményeként egy újabb töredékes koponya és néhány további csont került elő. Mindkét leletet Németországban preparálták, és végül a második koponya Berlinben maradt (RIEPPEL 2001, ÓSI 2012). A Placochelys típuspéldányáról 2017-ben a Continental cég segítségével Micro CT felvétel készült, mely nagyban hozzájárul e csodás, 3D-ben megőrződött Placodontia-lelet agyüregének és egyéb belső anatómiai jegyeinek (pl. a fogváltás folyamatának) vizsgálatához.

A Placochelys leletei mellett néhány izolált Placodontia fog is ismert a Jeruzsálem-hegy triász rétegeiből. Továbbá a hazai Placodontia-leletanyagot gazdagítja egy, a híres felsőörsi anisusi-ladin határszelvényből előkerült Paraplacodusnak határozott alsó állkapocstöredék, illetve egy izolált fog töredéke a Keszthelyi-hegységbeli Rezi Dolomitjából (GERE et al. in press). Az izolált leletek között akad még egy Nothosauria-csigolya a Mecsek anisusi korú rétegeiből továbbá egy töredékes Nothosauria alsó állkapocs a Balatonfelvidékrôl (BODOR \& MAKÁDI 2016, Ốsı et al. 2013).

Az 1960-as években a bihari a Réz-hegységben földtani kutatások során középső-triász (anisusi) gerinces fosszíliák kerültek elő. Az elsô szisztematikus gyújtések JURCSÁK Tibor vezetésével 1969-ben Sólyomkőpestes (Peştiş) mellett a Lion-völgyben kezdődtek, majd a '70-es években a szomszédos Felsô-Lugason (Lugaşu de Sus) folytatódtak (VENCZEL 1998). A több mint tíz éven keresztül tartó gyújtéseket a nagyváradi múzeum munkatársa, JURCSÁK Tibor végezte, és eredményeit több rövid közleményben is publikálta (JURCSÁK 1975, 1976, 1978, 1988). Bár a leletanyag döntôen izolált csontmaradványokból áll, jó megtartású csontok, fogak, állkapcsok és olykor még részleges koponyák is elôkerültek, melyek alapján egy igen diverz, döntôen tengeri gerinces fauna egykori jelenléte rajzolódott ki. Halak fosszíliái mellett dominánsan tengeri hüllők, köztük Nothosauriák (1. ábra A), Placodontiák, Ichthyosauriák és korai teknősök csontjai, továbbá a felettébb különleges Tanystropheus rendkívül megnyúlt nyaki csigolyái (1. ábra C) képviselik a leletanyagot (JURCSÁK 1973, 1975, 1976, 1977, 1978, 1982, 1988; HuZA et al. 1987; PoPA et al. 1996). A tengeri gerinces leletek mellett egy izolált fog ad hírt szárazföldi ragadozók jelenlétérôl az egykori partvidéken (HuZA et al. 1987). A bihari triász gerinces-leletanyag rendkívül fontos a triász időszaki gerincesek diverzitása és állatföldrajzi értelmezése szempontjából. A leletek revíziója időszerú lenne, ám a nagyváradi Körösvidéki Múzeumban ôrzött leletanyag költözési és egyéb munkálatok miatt már hosszú ideje nem hozzáférhető.

A Tiszai főegység Villány-Bihari egységén belül szerencsés módon nem csak Nagyvárad környékéről ismerünk triász időszaki csontokat. Az 1980-as években a villányi siklóbevágás területén feltáruló ladin korú Templomhegyi Dolomit és karni korú Mészhegyi Formáció rétegeinek dokumentálása során RÁLISHNÉ FELGENHAUER Erzsébet néhány töredékes csontleletet talált (RÁLISH-FELGENHAUER 1981). A felfedezés azonban nem az elsố területen: már LŐRENTHEY (1907) hallgatói terepgyakorlati gyújtések után csontokat említ a villányi vasútállomással szemben található kőfejtő rétegeiből. A Villány triász időszaki rétegei tehát ott hordozták magukban a lehetőséget egy komolyabb leletanyag felfedezésére, ami végül 2012-ig váratott magára. A siklóbevágástól mintegy 300 m-re nyugatra a Somssichhegy lábánál egy akkor éppen aktív építkezési területen apró, vöröses színú csontokat talált PozsGAi Emília, a Pécsi Tudományegyetem akkori doktorandusza. A felfedezést az 
ELTE Lendület Dinoszaurusz Kutatócsoport gyújtései és évenkénti, többhetes ásatásai követték, melynek eredményeként mára egy több ezer leletből álló, partközeli, sekélytengeri környezetben létezett diverz tengeri gerinces faunát ismertünk meg (ŐsI et al. 2013, BotFALVAI et al. 2019). A leletanyagot főként porcos és csontos halfogak és pikkelyek ezrei (SZABÓ et al. 2019), Placodontia (GERE et al. in press) és Nothosauria (SEGESDI \& Ôsı beküldve) ôshüllők kopo-

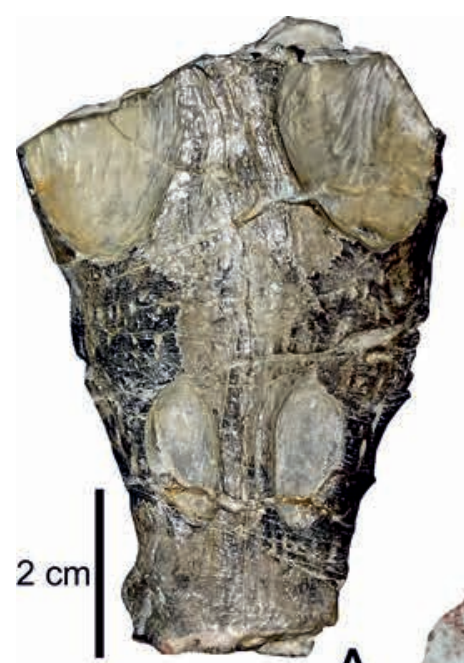

A

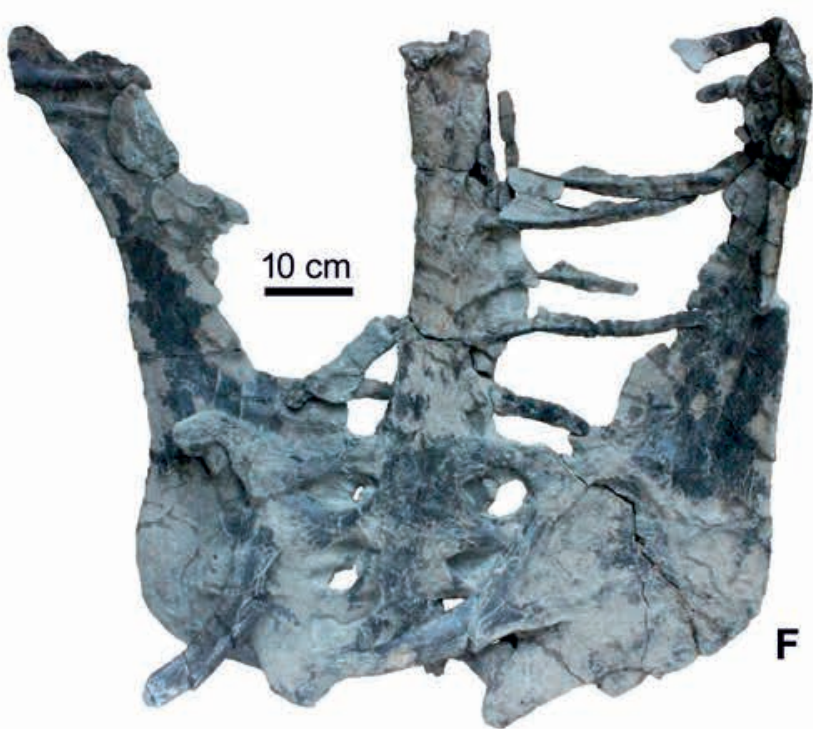

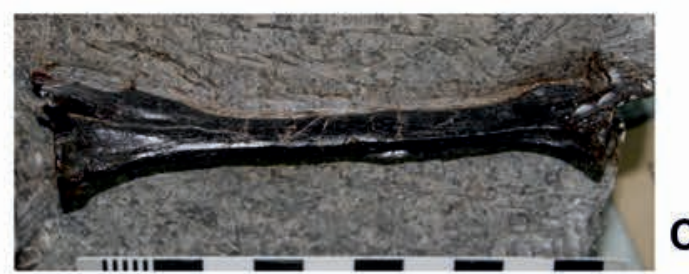

C
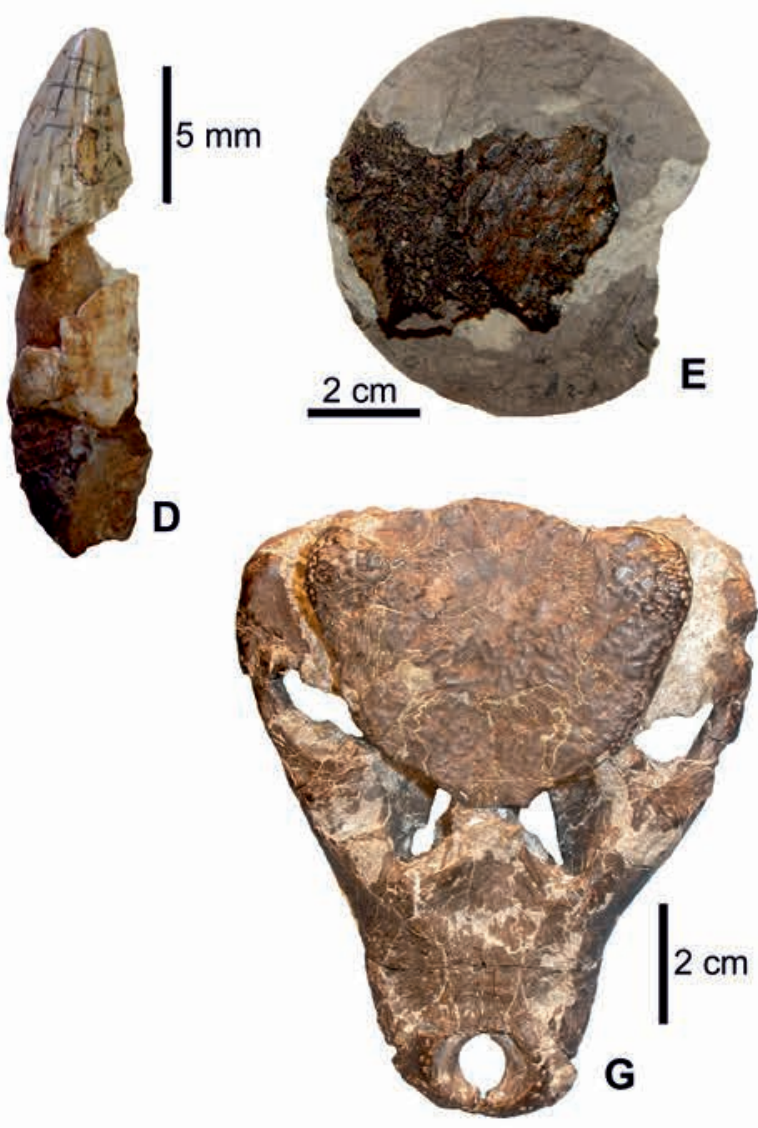
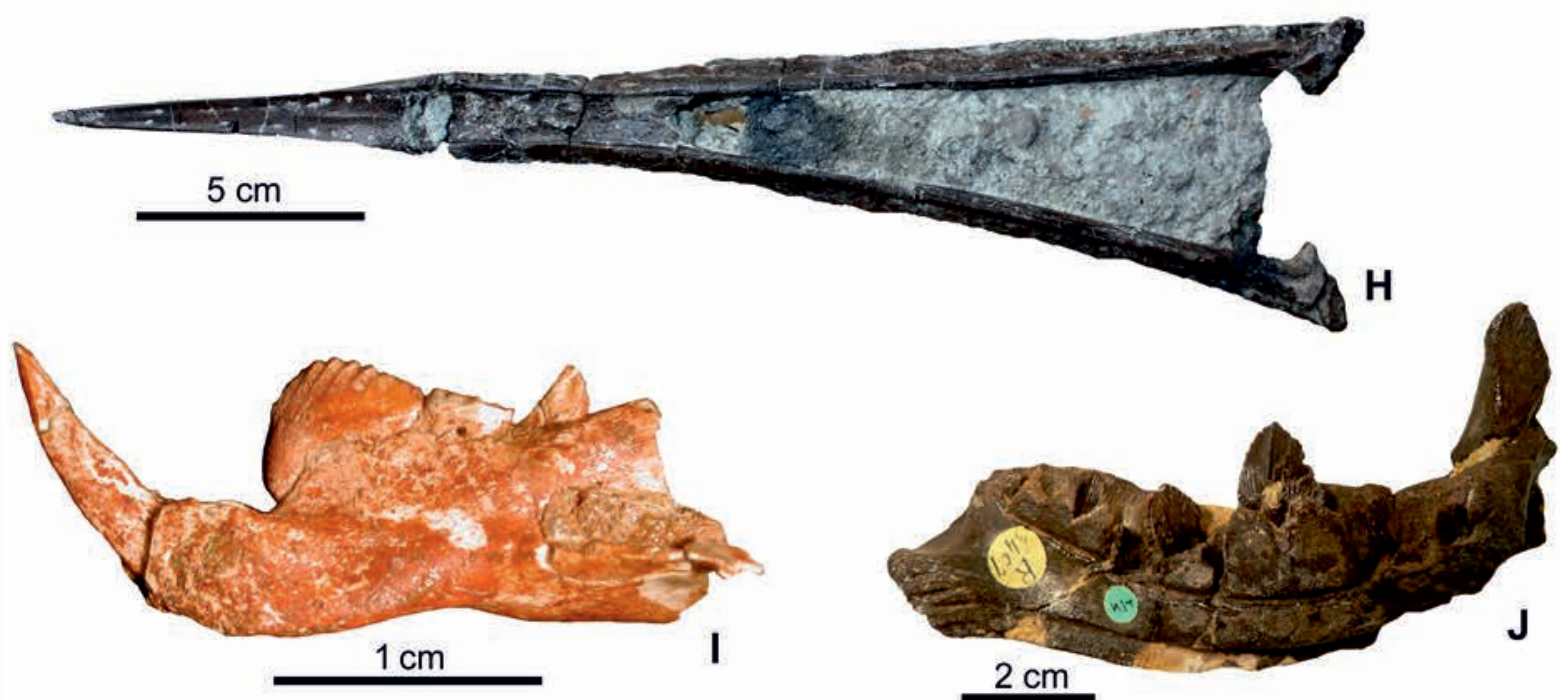
nyái, állkapcsai (1. ábra B) és postcranialis csontelemei alkotják. Ezek mellett a Biharból már említett, hosszú nyakú Tanystropheus 20 cm-t meghaladó nyaki csigolyái, továbbá más, részben szárazföldi Archosauromorpha ôshüllők fogai gazdagítják a villányi triász gerinces leletanyagot (Ốsı et al. 2020). A villányi leletanyag jelentősége abban áll, hogy a Biharból származó leletekkel együtt a középső- és felsôtriász Tethys-óceán északi partjának egy olyan vidékéről adnak információt a sekélytengeri-szárazföldi gerincesekre vonatkozóan, amelynek faunájáról korábban jószerivel semmit sem tudtunk.

\section{Jura}

A jura időszakból származó legkorábbi (hettangi) gerinces leletek a Kárpát-medencében a mecseki dinoszaurusz lábnyomok. Az elsô példányaik még az 1960-as években kerültek elő (TASNÁDI KUBACSKA 1967), ezek elég rossz megtartásúak voltak. A '80-as évek elején további lábnyomok láttak napvilágot a Mecsek területén (KoRDOS 1981), melyek alapján KoRDos (1983) Komlosaurus carbonis néven publikálta azokat. Az 1988-as nagy felfedezéseknek köszönhetően ugrott meg jelentősen a lábnyomos felületek száma. Míg a pécsbányai külfejtés területén az ELTE geológus hallgatói és oktatói, addig a vasasi külfejtésben a Magyar Állami Földtani Intézet munkatársai fedeztek fel és gyưjtöttek be több száz, lábnyomokkal teli kőlapot, melyeket aztán Budapestre szállítottak. Míg a Földtani Intézet által gyújtött példányok egy részét KoRDOs $(1989,2005)$ dolgozta fel, az egyetemisták által gyújtött, mintegy 75 lábnyomot tartalmazó, két hatalmas kôfelület darabjai csak 23 évvel később kerültek részletes dokumentálásra (HIPs et al. 1988, Ôsı et al. 2005a, 2011b). Érdekesség, hogy bár nyomok a Mecseki Kőszén Formáció több rétegéből is előkerültek, a nyomokat hátrahagyó állatok csontjai vagy egyáltalán bármilyen szárazföldi gerinces maradványa nem ismert e rétegekből. Mint ismeretes, a Mecseki Kőszén Formáció legalsó rétegei még a triász időszak legvégén, édesvízi körülmények között rakódtak le, majd felfelé haladva és már a jurába átérve egyre inkább erôsödött a tengeri behatás. Érdekes volna tudni, hogy vajon a triász-jura határ alatti rétegben lehetnek-e ilyen lábnyomok, vagy esetleg ott másfajta lábnyomokat találhatnánk. Hiszen, ha hasonló lábnyomok ott is előfordulnának, akkor ezek a két lábon járó, 2-2,5 méteres testhosszúságú, feltehetően korai Theropoda dino- szauruszok a szó szoros értelmében átsétáltak a triász-jura határon!

A mecseki dinoszaurusz lábnyomokat leszámítva a többi jura időszaki gerinces lelet szórványos maradványnak tekinthető hazánkban, és mind tengeri állatoktól származik. Ismerünk közel teljes halfosszíliákat a mecseki Réka-völgy anoxikus eseményt jelzô, toarci lemezes mészkő rétegeiből és a szintén toarci korú, úrkúti mangánércben található foszfátgumókból (SZABÓ \& PÁLFY 2020), továbbá izolált halfogak leletegyütteseit több különböző jura időszaki kőzetrétegből (SzABó 2020).

1996-ban került elő egy krokodil részleges csontváza a gerecsei Pisznice-hegy alsó-jura (toarci) vörös, gumós mészkő és márgarétegeiből (Kisgerecsei Márga Formáció), melynek részletes vizsgálata egy új, a tengeri krokodilok evolúciója szempontjából rendkívül fontos átmeneti formát igazolt. Felfedezójéról, FITos Attiláról a lelet a Magyarosuchus fitosi nevet kapta (Ôsı et al. 2018).

A Magyarosuchus csontvázával közel azonos rétegtani szintben, csak a Gerecse egy másik kőfejtőjében került elô egy részleges Ichthyosauria csontváza, melynek feldolgozása folyamatban van (DUNAI 2012).

\section{Kréta}

A kréta időszak már sokkal gazdagabb és izgalmasabb a gerinces leletek tekintetében. Míg egyes lelőhelyeket a véletlennek köszönhetően fedeztek fel, másokat a tudatos kutatás hozott napvilágra. Akárhogyan is, mára a kréta időszaknak három különbözô periódusából is van diverz, értékelhető gerinces fauna a Kárpát-medencéből.

A legidősebb közülük a Bihar hegységben található Cornet egykori bauxitbányainak berriázi leletegyüttese. Itt az első leleteket az 1970-es években fedezték fel, méghozzá egészen kivételes körülmények között, bauxitból kerültek elő csontmaradványok. Ezt követôen további gyújtések történtek, melynek eredményeként végül több mint tízezer csontlelet látott napvilágot. Rossz megtartásuknak köszönhetôen azonban taxonómiai szempontból csak néhány száz lelet értékelhető. A leletekkel elsőként a már korábban említett JURCSÁK Tibor, továbbá Elisabeta POPA és KESSLER Jenő foglalkoztak, később Erika Posmoşanu a nagyváradi Körösvidéki Múzeum munkatársa, majd külföldi kollégák kapcsolódtak be a leletek vizsgálatába (DYKE et al. 2011).

A leletanyag a hasonló korú kontinentális gerinces fau-

$\leftarrow$ 1. ábra. Gerinces leletek a Kárpát-medence mezozoikumi rétegeiből.

A) Nothosauria-koponya a Bihar-hegység középső-triász rétegeiből (Segesdi M. felvétele). B) Nothosauria-mandibula Villány középső-triász rétegeiből. C) Tanystropheus nyaki csigolya a Bihar-hegység középső-triász rétegeiből. D) Mesoeucrocodylia indet. krokodilfog az albai korú Alsóperei Bauxitból. E) Ankylosauria-páncélelem a Káptalanfa-2 fúrás mélyén harántolt, santoni korú Ajkai Kőszén rétegeiből. F) Hungarosaurus páncélos dinoszaurusz részleges csontváza a santoni Csehbányai Formációból Iharkútról. G) A növényevó Iharkutosuchus makadii holotípus koponyája a santoni Csehbányai Formációból, Iharkútról. H) Az azhdarchid repülő hüllő, Bakonydraco galaczi holotípus alsó állkapcsa a santon Csehbányai Formációból, Iharkútról. I) Barbatodon transylvanicus multituberculata ősemlős alsó állkapcsa az erdélyi Hátszegi-medence maastrichti rétegeiből (Csiki-Sava Z. felvétele). J) Zalmoxes robustus alsó állkapcsa az erdélyi Hátszegi-medence maastrichti rétegeiből (Csiki-Sava Z. felvétele)

$\leftarrow$ Figure 1. Vertebrate finds from the Mesozoic beds of the Carpathian Basin

A) Nothosauria skull from the Middle Triassic of the Bihar Mountains (photo by M. Segesdi). B) Nothosauria mandibula from the Middle Triassic of Villány. C) Cervical vertebra of Tanystropheus from the Middle Triassic of the Bihar Mountains. D) Mesoeucrocodylia indet. crocodile tooth from the Albian Alsópere Bauxit. E) Ankylosaurian armor from the Santonian Ajkai Coal layers of the Káptalanfa-2 borehole. F) A partial skeleton of an armored dinosaur from Hungarosaurus from the Santonian Csehbánya Formation of Iharkút. G) The skull of the herbivore Iharkutosuchus makadii holotype from the Santonian Csehbánya Formation of Iharkút. H) The lower jaw of the azhdarchid flying reptile, Bakonydraco galaczi holotype from the Santonian Csehbánya Formation of Iharkút. I) Barbatodon transylvanicus multituberculate mammal lower jaw from the Maastrichtian of Hateg Basin, Transylvania (photo by Z. Csiki-Sava). J) Lower jaw of Zalmoxes robustus from the Maastrichtian of Hateg Basin, Transylvania (photo by Z. Csiki-Sava) 
nákkal ellentétben eléggé szokatlan összetételû: Ankylosauria, Ornithopoda, nem madár Theropoda dinoszauruszok, madarak és különféle repülő hüllők töredékes csontjai kerültek elő (JURCSÁK \& POPA 1978, 1979, 1983, 1984; JuRCSÁK 1982; PATRULIUS et al. 1983; KESSLER 1984; KESSLER \& JURCSÁK 1984a, b, 1986; JuRCSÁK \& KeSSLER 1986, 1987, 1991; MARINESCU 1989; BENTON et al. 1997; PosmoşANU \& COOK 2000; PosmoşANu 2003a, b, c; DYKE et al. 2010). Bár az ostracodák és csigák részben édesvízi környezetre utalnak, a szinte minden hasonló korú lelőhelyrôl ismert kétéltúek, teknősök és krokodilok maradványai innen nem kerültek elő, ami talán összefügghet a csontok felhalmozási körülményeivel (PosmosAnU \& CoOK 2000).

Néhány millió évet előre ugorva az időben, meg kell említeni az albai korú alsóperei bauxitos agyagban talált csontokat Olaszfalu határából. Bauxitkutatás során az egyik kutatógödörben NoszKY Jenő egy töredékes fogat (1. ábra $D$ ) és néhány fehéres színú, apró csonttöredéket fedezett fel. A fog részletesebb vizsgálata alapján KRETZOI \& NOSZKY (1951) azt egy krokodil fogának azonosította. A recézett, lapított fog évtizedekkel későbbi újravizsgálata megerôsítette a krokodilokhoz való tartozást, és a csoporton belül két lehetséges klád jelenlétére szúkítette a rokonságot (Ősı et al. 2015). Néhány évvel ezelőtt megindult az Olaszfalu határában található Boszorkány-hegy bauxitkutató gödreinek újravizsgálata és gerinces leletek keresése. A kutatások eredményesnek bizonyultak, és további maradványok, köztük hal- és krokodilfogak és csonttöredékek kerültek napvilágra (MAKÁDI et al. 2019).

A hazai mezozoikumi gerinces lelőhelyek közül talán a legismertebb és legváltozatosabb a 2000-ben felfedezett iharkúti ősgerinces lelőhely. A lelőhelyen a csonttartalmú kőzetrétegek a felső-kréta bauxit fedôjében a santoni korú, folyóvízi, ártéri környezetben képződött Csehbányai Formáció homokköves, agyagos rétegsorában találhatók. Az elmúlt 20 év ásatásainak eredményeként mára közel százezer csontmaradvány, köztük részleges csontvázak, koponyák, állkapcsok kerültek eló, melyek legalább 40 különféle gerinces állatról tanúskodnak. Halak (SZABÓ et al. 2016a, b; SZABÓ \& Ősı 2017), farkos és farkatlan kétéltűek (SZENTESI \& VENCZEL 2010, 2012; SZENTESI et al. 2013), vízi és szárazföldi teknősök (RABI et al. 2012), szárazföldi gyíkok (MAKÁDI 2006, 2013a, b), édesvízi moszaszauruszok (MAKÁDI et al. 2012), növényevő (Ốsı et al. 2007, 1. ábra G) és ragadozó krokodilok (RABI \& SEBŐK 2015), repülő hüllók (ŐsI et al. 2005b, 2011a, 1 . ábra $H$ ), valamint különféle növényevô ( 1 . ábra $F$ ) és ragadozó dinoszauruszok (ŐsI 2005, ỐsI et al. 2010a, b, 2012, 2019), továbbá madarak (Ősı 2008, DYKE \& Ősı 2010) alkotják a különleges faunát (Ősı et al. 2012). A leletegyüttest gazdag tojáshéj (ProndvaI et al. 2017) és koprolit (SEGESDI et al. 2017) anyag egészíti ki, melyek — a sok-sok növénymaradvánnyal egyetemben - nagyban hozzájárulnak az egykori környezet paleoökológiai értékeléséhez (BODOR \& BARANYAI 2012, BOTFALVAI et al. 2015).

Az iharkúti gerinces lelőhely szedimentológiai vizsgálata (BotFAlVAI et al. 2016) és az egyes faunaelemek részletes dokumentálása többségében megtörtént. A megtalált leletek az európai kréta időszaki szigetfaunák egy új, ismeretlen világába nyújtanak bepillantást, és santoni korukkal nagymértékben hozzájárulnak a kréta ôsállatföldrajz pontosabb felderítéséhez (CsIKI et al. 2015). Bár a hazai leletanyag család szinten nagy arányban megegyezik a többi késő- kréta gerinces lelőhelyekével, a hosszú távú elszigetelt fejlődést jól mutatja a számos új, sok esetben egészen különleges forma megjelenése. Ezek között említhető a páncélos dinoszauruszok között szokatlanul filigrán felépítésú, kurzoriális mozgású Hungarosaurus vagy az egyedi, sok kúpot viselő őrlőfogakkal rendelkező, növényevő krokodil, az Iharkutosuchus.

Az iharkúti lelőhely mellett az Ajka környékén előforduló, szintén felső-kréta (santoni) Ajkai Kőszén kutatása is megkezdődött, és komoly, értékelhetô leletanyag került elô (Ősı et al. 2016). A maradványok döntő többsége mikrogerinces lelet, de ismert közel egy tucat nagyobb méretú csontlelet is. A leletek egy része fúrásokból (1.ábra $E$ ), más része a meddőhányókról származó kőzetdarabokból, és nagy többségük a csinger-völgyi Bocskor-árok területén felszínre bukkanó Ajkai Kőszén rétegek iszapolásából származik. Halak és krokodilok fogai a leggyakoribb leletek, emellett ritkábban moszaszaurusz és dinoszaurusz fogak és csontelemek is előkerültek. Bár az Ajkai Kőszén és a Csehbányai Formáció képződési környezete eltérô volt, az egykori lápi, mocsári környezetben lerakodott ajkai kőszenes rétegek fauna-összetétele kevésbé diverz, és az Iharkútról megismert faunaelemek fordulnak csak elő.

Végül a legfiatalabb mezozoikumi gerinces maradványok az Erdélyi-medence területérôl származnak. Ennek a hatalmas és rendkívül diverz, döntôen maastrichti korú leletegyüttesnek az első darabjait báró Nopcsa Ferenc húga, NopCSA Ilona fedezte fel éppen 125 évvel ezelőtt, melyeket aztán a báró számos, azóta is sokszor hivatkozott munkájában publikált (pl. NoPCSA 1902, 1915, 1929). Nopcsa $1933-$ as halálát követôen néhány évtizedig nem kutattak gerinces leletek után ezen a területen, mígnem a román kollégák a '60-as és '70-es években vették fel újra a fonalat. Az azóta eltelt évtizedek alatt többek között a bukaresti, dévai és kolozsvári kollégák dolgoztak és dolgoznak az újabb felfedezéseken (1. ábra $I, J)$, melyek jócskán kibővítették és új megvilágításba helyezték az erdélyi késő-kréta ősgerincesekrôl alkotott képünket (lásd pl. WeISHAMPEL et al. 1991, 2003; GRIGORESCU \& HAHN 1987; GRIGORESCU et al. 1985, 1990, 2010; CSIKI \& GRIGORESCU 1998, 2000; CSIKI et al. 2010a, b, c; BENTON et al. 2010; VREMIR et al. 2013, 2015; VENCZEL \& CODREA 2019).

\section{Paleogén}

A Kárpát-medence paleocén gerinces élővilágáról szinte semmit nem tudunk. Egyetlen jelentés az erdélyi Zsibó (Jibou) környékérôl szól, ahol a ma Róna Mészkő Formációként ismert rétegekből Косн (1900) édesvízi teknőscsontokat írt le. A leletek revízióját VREMIR \& CODREA (1996) majd VRemir (2004) végezte el, és a Palaeochelys nemzetségbe sorolták. 
Az eocén és oligocén korokhoz kapcsolódóan jórészt csak szórvány lelőhelyek maradtak fent. Áttekintő munkájában Kordos (1978) 19 eocén és 20 oligocén lelőhelyet sorol fel hazánk területérôl, amelyek közül 36 mindössze egyetlen meghatározható leletet szolgáltatott. A Kárpát-medence egészére nézve a leggyakoribb gerinces maradványok a hal-, azon belül is cápafogak, melyek igen nagy változa- tosságot mutatnak (CiOBANU 2002). Néhány lelőhelyről, például Nyírespusztáról (Ốsı 2001), Iszkaszentgyörgyről vagy Kolozsvár (Cluj-Napoca) környékéről (LóRENTHEY 1903, BRASSÓI FUCHS 1994, VREMIR 2004) határozható teknôsmaradványok (2. ábra $G$ ) kerültek elő, hírt adva többféle, fôként édesvízi csoportról. Jóval gyakoribbak a tengeri tehenek (KoRDOs 1977) vagy cetek csontjai (KoRDOS 1992),

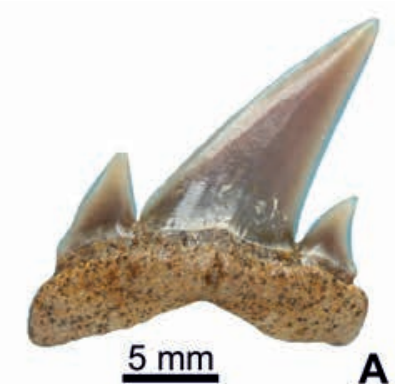

A

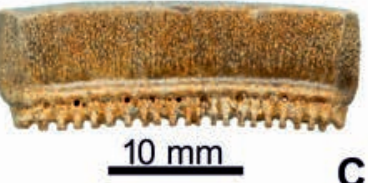

C

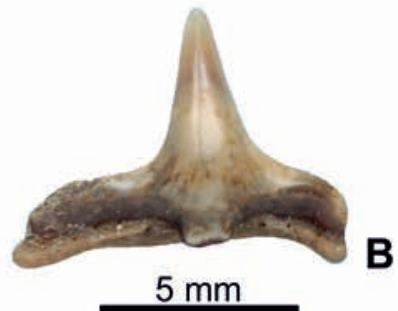

B
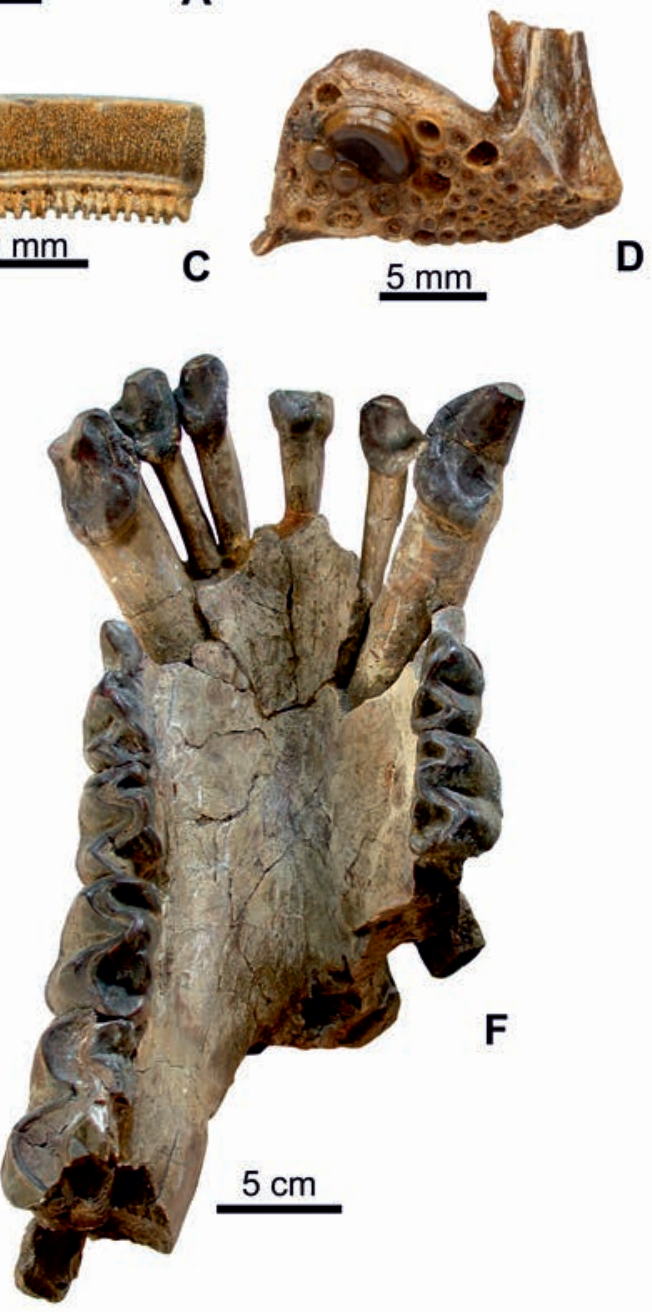
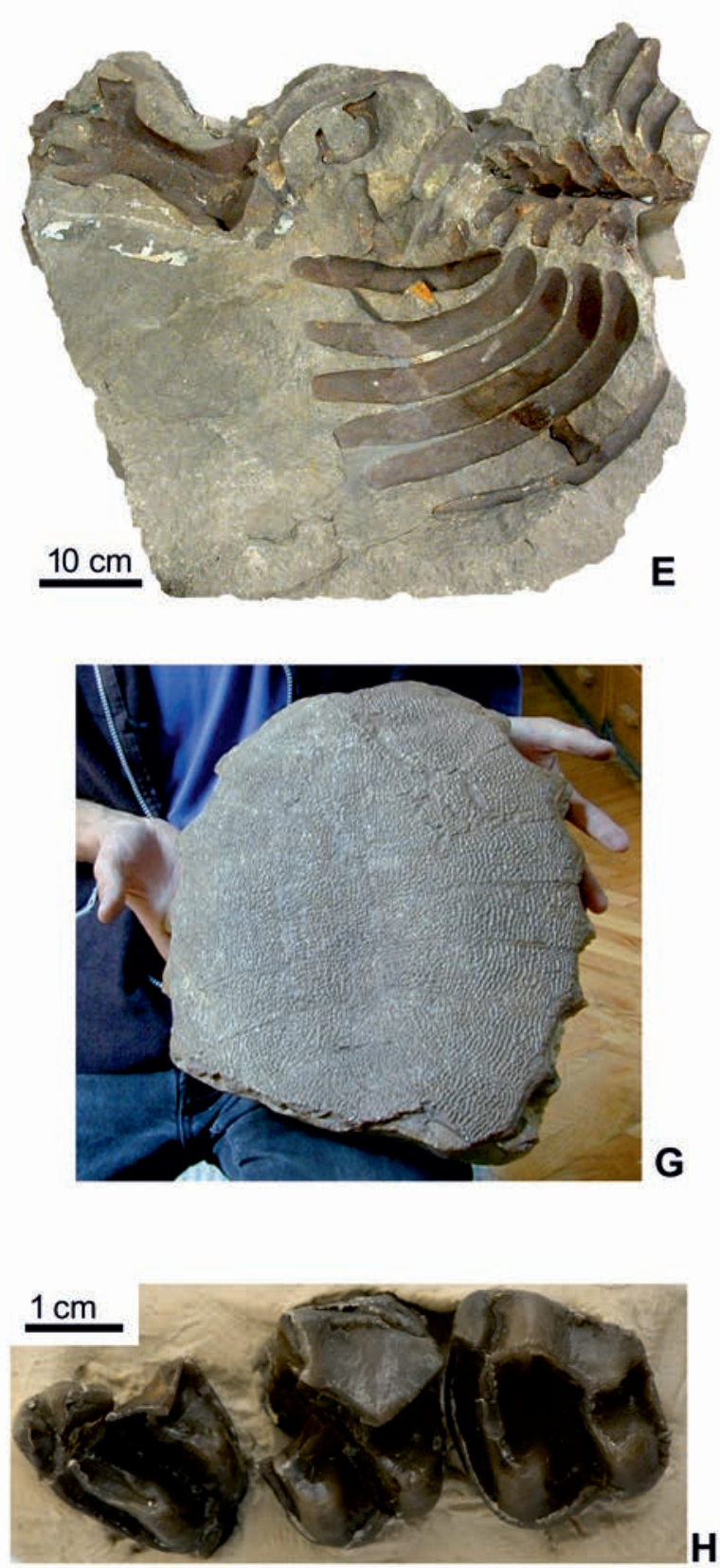

2. ábra. A-D, Halfogak és állkapocs

A) Carcharoides catticus, B) Squatina sp., C) Rhinoptera studeri, D) Sparidae indet. az Úny-Máriahalom melletti oligocén homokbányából (Szabó M. felvételei). E) Szirén részleges csontváza a tatabányai középső-eocénből (Fözy I. felvétele). F) Brachydiastematherium transylvanicum alsó állkapcsa a Kolozsvár melletti felső-eocénből (Főzy I. felvétele). G) Trionyx sp. hátpáncélja a kolozsvári eocénből (Főzy I. felvétele). H) Hyrachyus cf. stehlini fogai a csordakúti eocénből (Főzy I. felvétele)

Figure 2. $A-D$, Fish teeth and jaw element

A) Carcharoides catticus, B) Squatina sp., C) Rhinoptera studeri, D) Sparidae indet. from the Oligocene sand mine near Úny-Máriahalom (photo by M. SzABó). E) a partial skeleton of a siren from the Middle Eocene of Tatabánya (photo by I. FöZY). F) lower jaw of Brachydiastematherium transylvanicum from the Upper Eocene near Cluj-Napoca (photo by I. FöZY). G) Trionyx sp. carapax from the Eocene of Cluj-Napoca (photo by I. FöZY). H) Hyrachyus cf. stehlini teeth from the Eocene of Csordakút (photo by I. FöZY) 
melyek között akadnak koponya- és fogazatdarabokat is tartalmazó részleges csontvázak is (2. ábra $E$ ). A vízi gerincesek leletei mellett elvétve szárazföldi állatok maradványai, leginkább fogak, állkapocs- és végtagcsont töredékek (BöcKH 1875, Kocsis 2002, KoRDOS 1992) is előfordulnak (2. ábra $F, H$ ).

Az oligocén jellegzetes, sok esetben laminált kôzeteiből (Kiscelli Agyag és Tardi Agyag Formációk) szép halfaunák ismertek (2.ábra A-D) a Kárpát-medence több lelőhelyéről, melyek gyakran teljes csontvázakat megőrző leletekből állnak (WeILER 1933; PAUCĂ 1934; BÖHM 1941, 1942; SOLT 1988; SzABÓ et al. 2017). E leletek taxonómiai revíziója és paleoökológiai értékelése időszerú és az egykori környezet pontosabb megértése szempontjából igen hasznos volna.

A szárazföldi gerinces leletek között ismert néhány informatív szórványlelet, köztük a KocH Antal által 1891-ben felfedezett és Kretzor (1943) által leírt Kochictis centenii koponyatöredékei, továbbá széndisznók (Anthracotherium), orrszarvúfélék és tapírok maradványai (KRETZOI 1940, 1941; CODREA 2000).

Az oligocén halfosszíliák és szórványleletek mellett csak néhány diverz fauna került elő ebből az időszakból. Ilyen például a felső-oligocén máriahalmi leletegyüttes (RABI \& BotFALVAI 2008), ahonnan igen érdekes ragadozómaradványok is származnak (RABI et al. 2018). Hasonlóan gazdag az oligocén bodajki kisemlósanyag (KRETzOI 1956a), amelynek a tudományos feldolgozása mindmáig nem történt meg.

\section{Alsó- és középsó-miocén}

Az ipolytarnóci a legkorábbi neogén lelőhelyünk, amely tudományos szempontból és a nagyközönség részéről egyaránt kitüntetett érdeklődésre tarthat igényt. A csaknem kétszáz éve felfedezett lelőhely több területen is kiemelkedő leleteket adott a hazai paleontológiának. Itt találták meg a világon a legnagyobb megkövült fatörzset, és ez a világ egyik leggazdagabb, ôslábnyomos lelőhelye (3. ábra A). Ezenfelül növényi és porcoshalleletek is nagy számban kerültek elő Ipolytarnócról.

A lábnyomok alsó-miocén folyóvízi környezetben képzôdött szürke homokkő felületén maradtak fenn. A korabeli homokos felszín a Kárpát-medence kora-miocén trópusi tengerpartjának közelében lehetett, ahol jelentôs vízfolyások futottak a tenger felé. Az édesvízi itatóhelyre vagy a vízparti táplálékforráshoz érkező állatok lábnyomai kiválóan megőrződtek a homokban, mert 17,4 millió évvel ezelőtt egy hatalmas vulkánkitörés vastag hamuréteggel temette be őket (PÁLFY et al. 2007).

A lábnyomos homokkövet az akkor már híres, óriási kovás fatörzs vizsgálata során, 1900-ban találta meg BöcKH Hugó selmecbányai akadémiai tanár és Tuzson János botanikus. BöcKH János a Földtani Intézet akkori igazgatója az 1900. évról szóló jelentésében részletes leírást ad a lábnyomos homokkőről. Az ezt követő évtizedekben a kutatómunka — elsősorban TASNÁDI KUBACSKA András vezetésével több szakaszban zajlott. A több mint 1000 négyzetméternyi homokkő felületen azonosított lábnyomok mennyisége meghaladta a háromezret, amivel Ipolytarnóc már ebben az idôszakban is a világ leggazdagabb lábnyomos lelőhelyének számított. Ugyanakkor a felismert fajok száma (4 madár, 4 ragadozó, 2 párosujjú patás, 1 orrszarvú) a felfedezés óta alig változott. Amikor KoRDos László az 1980-as évektől bekapcsolódott a kutatásokba, a korszerú taxonómiai revízió alapján a következő fajok szerepeltek a faunalistában: Rhinoceripeda tasnadyi, Rh. tasnadyi (juvenilis), Pecoripeda cf. amalphaea, Megapecoripeda miocaeniea, Ornithotarnocia lambrechti, Avidactyla media, Mustelipeda punctata, bizonytalan nyomok (Proboscidea?), Bestiopeda sp., azonosíthatatlan nyomok, Tetraornithopedia tasnadii, Passeripeda ipolyensis, Carnivoripeda nogradensis, Bestiopeda maxima (KoRdos 1985a).

A Bestiopedia maxima volt a lelőhely talán legérdekesebb faja. Ez egy hatalmas ragadozó lábnyoma, amelyet a grizzly méretű „medvekutyával” (Amphicyon) azonosítanak a kutatók.

2014-ben a kutatásoknak egy teljesen új fejezete nyílt meg, amikor KoRDOs László és MÉsZÁros Ildikó optikai és digitális módszerekkel újravizsgálták a már eddig ismert homokkő felületeket és további ásatásokat is végeztek. Az innovatív megközelítés segítségével sok ezer új lábnyomot mutattak ki, és legalább harminc új fajt azonosítottak (KoRDOS, személyes közlés). Az új lábnyomok nemcsak taxonómiai szempontból jelentôsek, hanem azért is, mert a most felfedezett állatok fóként a vízben éltek (pl. krokodilok, teknősök, békák), és ökológiai szempontból jelentősen hozzájárulnak annak az ökoszisztémának a teljesebb rekonstruálásához, amelynek eddig csak az itatóhelyre járó szárazföldi tagjait ismertük.

A lábnyomos lelőhellyel szomszédos vízmosás cápafogas rétegeit elsőként $\mathrm{KoCH}$ Antal paleontológus tárta fel 1903-ban. A szárazföldi képződmények feküjében, egyes kora-miocén (eggenburgi) tengeri homokkő rétegekből gazdag porcoshal (cápa, rája) fauna került elő (Косн 1903). A leletek korszerú újraértékelését, újabb gyújtésekkel is kiegészítve Kocsis László (2007) végezte el, aki a taxonómiai revízión felül geokémiai vizsgálatokat is folytatott az anyagon (Kocsis et al. 2009).

A cápafogak rossz megtartási állapota, töredezettsége, kopottsága azt sugallja, hogy ezek lerakódásuk után akár többszörösen is áthalmozódhattak, illetve erős áramlások által szállítódhattak, koptatódhattak. A fauna igen változatos: 19 cápanem képviselői kerültek elő a rétegekből, köztük a Carcharias és Carcharhinus nemek dominálnak. Ezekre a meleg mérsékelt és trópusi elterjedés, illetve elsősorban a partközeli, sekélyebb környezet jellemző. A fauna tartalmaz néhány kifejezetten trópusi (Hemipristis), illetve boreális (Squalus) alakot is. Ritkábban előfordulnak nyílt (Isurus, Alopias) és mélyebb (Mitsukurina, Odontaspis, Isistius, Centrophorus) vízi taxonok is. Az oxigénizotópos adatok általában összhangban vannak a fauna általánosan meleg mérsékelt, szubtrópusi, de kissé kevert összetételével. A stronciumizotópos adatok 18.5 \pm 0.5 millió évet adnak, ami későeggenburgi — kora-ottnangi kornak felel meg (Kocsis 2016). 

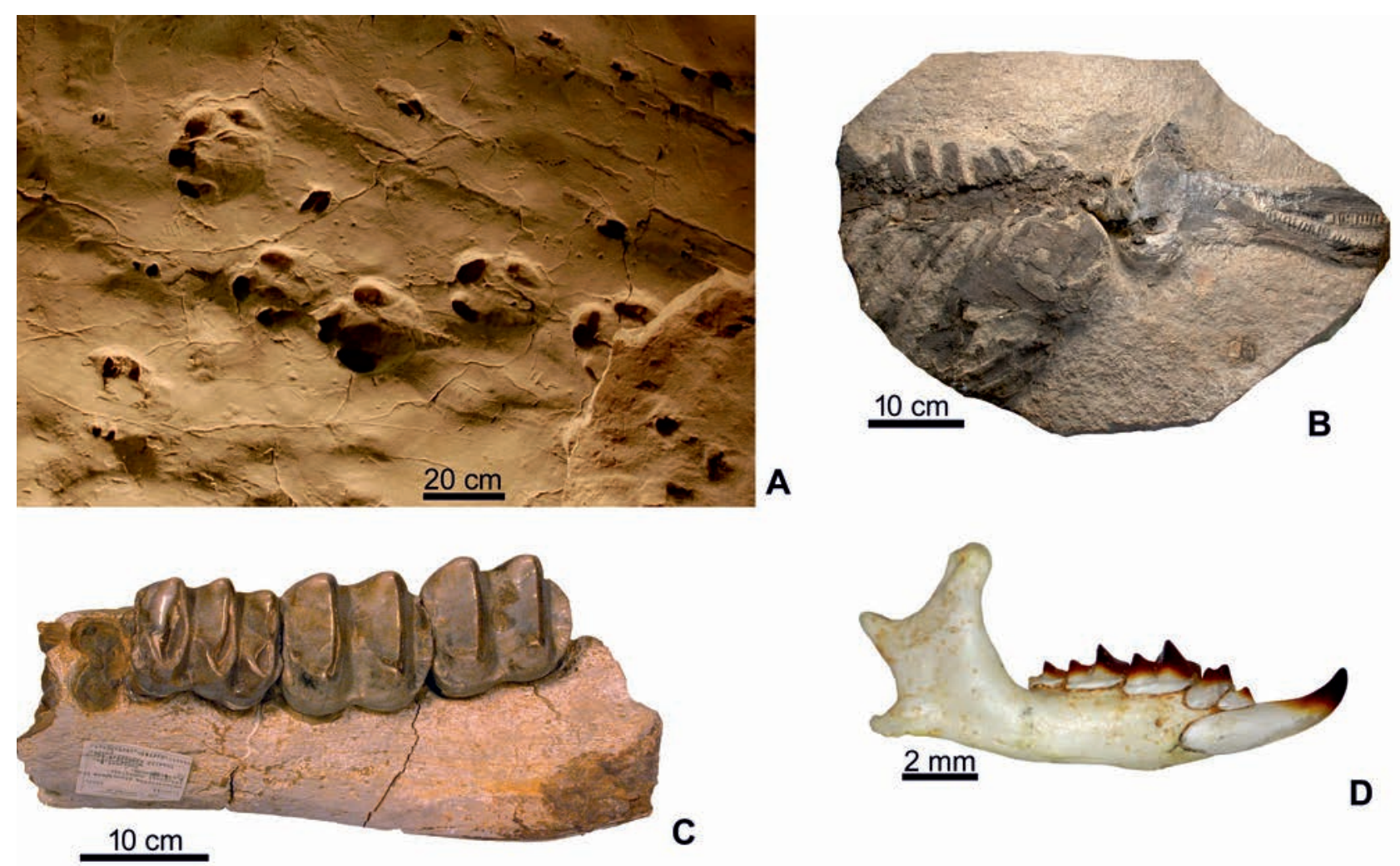

D
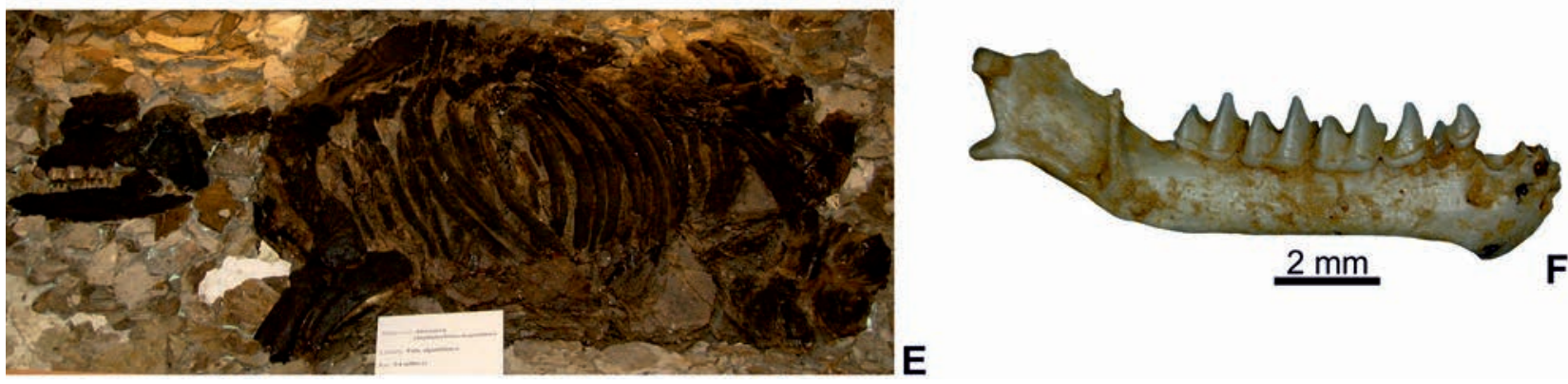

3. ábra. A) Miocén ősorrszarvú lábnyomok Ipolytarnócról (FőzY I. felvétele). B) Heterodelphis csontváza a szentmargitbányai badeni korú Lajta Mészkőből (FőzY I. felvétele). C) Deinotherium alsó állkapcsa kőbányai pannóniai rétegekből(FöZY I. felvétele). D) A Kárpát-medence egyik emblematikus kisemlőse a Beremendia fissidens „óriáscickány” jobb alsó állkapcsa a pleisztocén Beremend-14 lelőhelyről. E) Pliocén ősorrszarvú egyik csontváza a pulai alginitbányából (FuTó J. felvétele). F) Myotis daubentoni denevérfaj jobb alsó állkapcsa Beremend-16 lelöhelyröl, amely a pleisztocénben hủvös, nedves éghajlatot jelez

Figure 3. A) Miocene rhinocerotid footprints from Ipolytarnóc (photo by I. FöZY). B) Skeleton of Heterodelphis from the Badenian Lajta Limestone of Szentmargitbánya (photo by I. FöZY). C) Deinotherium lower jaw from Pannonian beds of Köbánya (photo by I. FöZY). D) Lower jaw of the Beremendia fissidens from the Pleistocene Beremend-14. E, a skeleton of a Pliocene rhinocerotid from the alginite mine of Pula (Hungary) (photo by J. FuTó). F, Right lower jaw of the bat species Myotis daubentoni from Beremend 16 site

A középsô-miocén vízi gerinceseket (3. ábra B) is szolgáltató lelőhelyek közül ki kell emelnünk a mecseki homokrétegeket. Ezek jórészt pannon képződmények, de az áthalmozódások miatt badeni és szarmata gerincesek maradványait is tartalmazzák. A mecseki lelőhelyek első irodalmi említése KRETzor Miklóstól (1955) származik. A leletek az ezt követő évtizedekben folyamatosan gyarapodtak (KoRDOS \& SolT 1984), és az 1990-es évek végére a kutatók és a magángyújtők több ezer csontmaradványt gyújtöttek be

A lelőhelyek közül a danitzpusztai homokbánya a legjelentôsebb. A homokból kivételes gazdagságban kerültek elő badeni, szarmata és későbbi (pannon) tengeri tehenek, fókák és cetek maradványai (KAZÁR et al. 2007). Ezek az izolált csontok az áthalmozódás miatt erósen koptatottak, teljes csontváz nem fordult elô. Ugyanakkor, a nagyszámú lelet számos, a cetek taxonómiájának körében írt publikáció alapjául szolgált (pl. CSERPÁK 2018; KAZÁR 2005, 2006).

A szárazföldi középső-miocénből a 20. század végéig viszonylag kevés leletanyag állt rendelkezésre. Ezen maradványok korszerú kutatásában KoRDOs László tette meg az elsố lépéseket a hasznosi és a szentendrei lelőhelyek leírásával (KORDOs 1986). Az utóbbi három évtizedben Hír 
János számos új faunát tárt fel és több, már régebben felfedezett lelőhelyet kutatott újra. Ezek közül a legjelentősebbek Sámsonháza, Mátraszőloos és Hasznos, ahonnan elsősorban gazdag kisemlősfauna került leírásra (HíR 2006, Hír \& MÉSZÁRos 2002, PRIETO et al. 2015), de a kétéltú, hüllő és madármaradványok is jelentősek (pl. VENCZEL \& Hír 2013). Hír János és Venczel Márton olyan határon túli területeken is folytatott feltáró munkálatokat, mint például Kománfalva (Comăneşti) vagy Tasád (Tăşad) (VENCZEL \& Hír 2008). A felső-miocén szárazföldi lelőhelyek általában mocsári, tavi, vagy lagúnafelhalmozódások, és legtöbbször meleg és nedves, szubtrópusi klímát jelzô faunát szolgáltattak.

\section{Felsó-miocén}

A rudabányai vasércbánya Rudapithecus hungaricus leletei és gazdag késô-miocén életközössége miatt hazánk talán legjelentôsebb kainozoikumi gerinces lelőhelye. Az ősmaradványokban gazdag rétegek a vasércbánya egyik meddőként felhagyott területén találhatók. Mintegy 10 millió éve ez a terület a Pannon-tó partvidékén helyezkedett el (BERNOR et al. 2004). A vöröses színú vasérces dolomit- és mészkő szirtek között a partra kifutó tó és mocsár vizében 6-10 m vastag, sárgásvöröses-szürke színú mocsári tarkaagyag, majd meszes agyagok és lignitrétegek halmozódtak fel, amelyből világszerte páratlan gazdagságú flóra és fauna maradványai — köztük az ôsmajmok csontjai — kerültek elő (KoRDOs 2015).

A rendszeres őslénytani ásatások néhány évvel a Rudapithecus 1965-ös felfedezése után, 1971-ben indultak meg Rudabányán, ahol a vasércbányászat még 1985-ig folyt. Eközben az elsô Rudapithecus lelőhelye 1972-ben egy földcsuszamlással gyakorlatilag megsemmisült. A rudabányai fauna legnagyobb része a közeli II. számú lelőhely alig 800 négyzetméternyi felületú és 2-3 m vastag üledékéből került elő (KORDOS 2015).

A kezdeti évtized munkálatait — amikor a leletmentés és a leletek minél többirányú ôslénytani feldolgozása volt jellemző — Kretzor Miklós (2002) vezette. Az 1980-as évektôl KoRDos László vette át az irányítást, és ezt követően a kutatások már a napjainkig használt négyzethálós dokumentációs rendszerben történtek, valamint a kutatásokat a bánya és környékének többi lelőhelyére is kiterjesztették. Az 1992 és 1996 közötti magyar-amerikai multidisziplináris kutatások a világ számos országából érkező specialisták bevonásával folytak (BERNOR et al. 2004), és a gazdag gerinces fauna átfogó rendszertani értékelése mellett a pontos földtani kort, a tafonómiai-szedimentációs, és paleoökológiai hátteret is felderítették (KORDOs 2015). A későbbiekben több nemzetközi együttmúködés keretében folyt feltáró munka a lelőhelyen (BEGUN 2007), és jelenleg is egy külföldi csoport végzi a kutatásokat David BEGUN irányításával (BEGUN 2020, GuNZ et al. 2020).

A lelőhely története tehát az első főemlőslelettel indult, amelyet 1965-ben talált meg HERNYÁK Gábor, a bánya geológusa. Az emberszerú ősmajom állkapocstöredékét KRET-
zOI Miklós Rudapithecus hungaricusnak nevezte el és felfedezését a Magyar Nemzet címú napilapban tette közzé 1967. október 10-én. Azóta közel háromszáz főemlős maradványa került elő Rudabányáról. Közülük a legjelentősebbek koponyaleleteket is tartalmaznak: 1975-ben egy hím egyed, 1985-ben egy idős nőstény, 1999-ben egy fiatal nőstény koponyáját, majd 2006 és 2009 között ugyanennek az egyednek az állkapcsát, medence- és combcsontpárját, valamint további végtagcsontjait tárták fel a kutatók. Az elsőnek felfedezett fajon kívül Anapithecus-maradványok is képviselik a korabeli ősmajmokat (KoRDos 2015). A ,Rudapithecus" leleteket a szakirodalom ma leginkább a Dryopithecus brancoi SCHLOSSER, 1901 fajba sorolja (BERNOR et al. 2004), de a vele kapcsolatban kialakult nevezéktani viták korántsem tekinthetők lezártnak, és lehetséges, hogy a konklúzió az lesz, hogy a KRETzor által adott név az érvényes. A rudabányai főemlős-maradványok a taxonómiai bizonytalanságtól függetlenül jelentős paleoantropológiai jelentőséggel bírnak, mert az emberré válás korai szakaszáról nemcsak alapvető morfológiai és filogenetikai (KORDOS \& BEGUN 2001, GUNZ et al. 2020), hanem jelentős ôsföldrajzi és paleoökológiai információkat is nyújtanak (EASTHAM et al. 2016).

KoRDOs (2015) áttekintő tanulmánya szerint a rudabányai mocsári-tavi és folyóvízi üledékek az egykori Pannontóba benyúló keskeny félsziget völgyeiben rakódtak le. Az éghajlat akkortájt a mai szubtrópusi és közepesen mérsékelt éghajlatú területek határán uralkodónak felelhetett meg. Az alacsonyabb térszíneken (közvetlenül a partokon) vízkedvelő fák nőttek, a hegyeket pedig dús, szubtrópusi erdôk borították. Az évi középhômérséklet $11-17^{\circ} \mathrm{C}$, az évi csapadékmennyiség 1100-1200 mm körüli lehetett.

Az ásatások sok ezer csontmaradványából több mint 100 gerinces fajt mutattak ki. A nagyemlősök között a növényevőket és a mindenevőket az ormányosok, orrszarvúak, háromujjú ôslovak, kérôdzốk, disznófélék, tapírok és az óriási termetû chalicotheriumok képviselték. Ragadozó-fosszíliák a többi csoporthoz képest kevesebben vannak, de előkerültek a vidrafélék, a medvefélék és hiénák maradványai. Az ipolytarnócról ismert hatalmas méretű ragadozó, az Amphicyon ennek a faunának is részét képezte. A kis termetú emlősök (rágcsálók és rovarevő́k) magas diverzitást mutatnak, és repülő emlősök (denevérek és repülőmókusok) is előfordultak itt. A madárkövületek ritkák a lelőhely anyagában. A mocsárban alig élt hal, de sok volt a béka és farkos kétéltű faj. A hüllőket nagyszámú kígyó és teknős képviselte (KoRdOs 2015, BERNOR et al. 2004, EASTHAM et al. 2016).

Rudabánya nem csak a világszinten jelentôs paleoantropológiai leletei miatt említésre méltó. Ez a lelőhely nyitja meg a felső-miocén leletegyüttesek sorát, amelyek páratlanul gazdag „Hipparion-faunát” szolgáltattak a pannon időszakból. A pannon folyamán a jelentős ősföldrajzi és éghajlati átalakulások, valamint faunavándorlások következtében a szubtrópusi, dús vegetációjú élővilág fokozatosan eltúnik, majd megjelenik a későbbi, nyíltabb, leginkább a mai szavannákra emlékeztető közösség. Közülüik itt csak néhányuk bemutatására van lehetőségünk. 
Az alsótelekesi fauna még a szubtrópusi, melegkedvelô életközösségekhez tartozik. A KoRDos László vezetésével 1993-ban megkezdett ásatások kiderítették, hogy a Rudabányához közeli Alsótelekes egykori gipszbányájának fedőrétegében az előbbi lelőhellyel egykorú, azzal összefüggő, ősmaradványokban gazdag mocsári-tavi-folyóvízi rétegek vannak. Ezekből 1997-ben a Rudapithecussal egy időben élt Anapithecus ősmajom fogát is sikerült kimutatni (KoRDOS 1997, MÉSZÁROS 1999b). A gyepüfüzesi (Kohfidisch) és a götzendorfi fauna időben és az ökológiai jellegzetességek tekintetében egyaránt átmenetet képez Rudabánya és a késôbbi lelőhelyek között (BACHMAYER \& SzYNDLAR 1985, BERNOR et al. 1991).

A Sümeg-gerinci karszthasadék-kitöltés már klasszikus Hipparion-faunát szolgáltatott. KRETZOI (1984) nagy számban írt le innen kétéltûeket, gyíkokat, teknôsöket, rovarevőket, denevéreket, rágcsálókat, Hipparion-féléket, orrszarvúakat és más patásokat, hiénákat és macskaféle ragadozókat. BERNOR et al. (1999) a sümegi Hipparionok fogzománc mikrokoptatottság-vizsgálatával pontosította a fauna élőhelyérôl alkotott képünket. Így ma már tudjuk, hogy ez a közösség még ebben az időben sem teljesen nyílt füves pusztákon, hanem kevert vegetációjú ökoszisztémában élt. A rovarevők a sümegi maradványok meglepóen nagy hányadát (25\%) teszik ki (MÉszÁROS 1999b), és jelentősen hozzájárultak a korabeli ökoszisztéma meghatározásához. KRETZOI (1954) az előzőnél valamivel fiatalabb, de még annál is gazdagabb Hipparion-faunát írt le a csákvári Esterházy-barlang üledékeiből.

A felsô-miocén szárazföldi ökoszisztémákban lezajlott globális környezetváltozások valódi hatásai a 7-8 millió éves bérbaltavári lelőhelyen mutathatók ki egyértelmúen. A Kárpát-medencében ekkorra már nemcsak a szubtrópusi erdők tûntek el, hanem az erdős szavannára emlékeztetó növényzet is visszaszorult. A hegységperem felől a medence belseje felé siető folyók üledéke egyre inkább feltöltötte a Pannon-tavat, és a kialakuló szárazulatokon füves puszták, sôt kifejezetten arid területek is megjelentek. Bérbaltavár Szőlő-hegyének homokjából a 19. század közepe óta kerülnek elő az ôsállatok errôl tanúskodó csontjai. A Hipparionfélék mellett kardfogú tigrisek, kapafogú őselefántok, orrszarvúfélék, hiénák, különféle ôsi patások és a korabeli élôvilág számos más jellemzô faja tanúskodott a hajdani eseményekről. Az 1860-tól több jelentôs ásatás is zajlott a területen. Csak Kormos Tivadar (mindössze három hétig tartó) 1913-as munkája során több mint 1000 leletet tárt fel és ezek alapján négy új fajt írt le (KoRMos 1914). Legutóbb 2000-2001-ben - magyar-amerikai tudományos együttmúködés keretében - KORDOS László és Ray BERNOR vezetésével, már pontos környezetrekonstrukciót is tartalmazó, korszerú kutatások folytak a területen (KoRDOs 2003).

A bérbaltavárihoz hasonló korú tardosbányai gerinces maradványok a Gerecse jura mészkövében kialakult karsztos hasadék agyagkitöltéséből kerültek elő, amelyet a kőfejtő munkálatai tártak fel. A leleteket JÁNOSSY Dénes gyưjtötte be, és miután előzetes faunalistát készített róluk, elhelyezte ôket a MÁFI (ma: Magyar Bányászati és Földtani Szolgálat) gyújteményében. A gazdag kisemlősanyagnak eddig a rovarevő és bizonyos rágcsáló fajait dolgozták fel részletesebben (KoRDOs 1985b, 1987; MÉSZÁROS 1998).

A Polgárdi határában húzódó Kőszár-hegy vonulata nagyrészt devon kristályos mészkőből áll (Polgárdi Mészkô Formáció). A jó minőségú kőzetet a rómaiak kora óta bányásszák, és az intenzív múvelés során számos olyan karsztosodott hasadék és barlang került elő, amelyek nemzetközi viszonylatban is gazdag, kitûnő megtartású faunát tartalmaztak. 1909 óta öt fosszíliatartalmú karsztüregkitöltést fedeztek fel (FreudENTHAL \& Kordos 1989), amelyek közül a 2. számú a „klasszikus” polgárdi lelőhely (KoRMOs 1911), de ez — bár számottevő mennyiségú ősmaradványt szolgáltatott, gazdagságában össze sem mérhető a 4-es és 5ös leletegyüttes anyagával. A páratlan anyag gazdagságát és kivételes megtartási állapotát jól érzékelteti, hogy MészÁROS (1999a) csak a cickányfajok feldolgozása közben 3000 körüli minimum egyedszámú mintával (zömében ép koponyák és állkapcsok) dolgozhatott. A statisztikus mennyiségben jelenlevố és a legtöbb morfológiai karaktert épen tartalmazó példányok számos új taxon felfedezését tették lehetővé (pl. ANGELONE \& ČERMÁK 2015). Innen került leírásra a KoRDOS László tiszteletére elnevezett rovarevő genus, a Kordosia is (MÉszÁRos 1997). Ennek a — családjában hatalmas méretúnek számító — „óriáscickánynak” a megtalálása nagy jelentőségû volt a ma is élő Anourosoricini csoport filogenetikai viszonyainak tisztázásában, és hozzájárult a Pannon-medence ősföldrajzi kapcsolatainak felderítéséhez is.

\section{Pliocén}

A pliocén lelőhelyek közül — különleges felhalmozódási körülményei miatt — mindenképpen említést érdemel a pulai alginitbánya. A Pula melletti, alginittel feltöltődött csaknem 4 millió éves vulkáni krátertavat 1973-ban fedezték fel. A bányamúvelés során több szintből kerültek elô levél- és ízeltlábú-kövületek, halak és emlősök maradványai (KATONA et al. 2014). A legjelentôsebb leletek a rendkívül jó megtartású orrszarvúcsontvázak (3. ábra E). A szenzációs maradványegyüttes a Bakonyi Természettudományi Múzeumba került, és azóta számos specialista szakember végzett kutatásokat a példányokon (KovÁcs et al. 2020). Vulkáni krátertó őrizte meg az ajnácskői (Hajnačka) „csontosárkok" leleteit is (VASS et al. 2000). 1863-óta tapírok, orrszarvúk, masztodonok, hódok, majmok és számos más állat csontjai kerültek elő az árkokból (KoRmos 1917). A fauna jelentőségét növeli, hogy Ajnácskő az MN16-os Zóna típuslelőhelye. Ivánháza (Ivanovce) egy másik meghatározó felvidéki lelőhely, amelynek karsztüregkitöltéseiből az 1950-es években pliocén nagy- és kisemlősök gazdag együttesét tárták fel (FEJFAR et al. 2012).

A „hagyományos” felhalmozódású pliocén lelőhelyek közül a csarnótai karsztüregkitöltésekben a 20. század kezdete óta KoRMOs Tivadar, majd JÁNOSSY Dénes és KRETZOI Miklós 4 lelőhelyet tárt fel (KRETZOI 1962). Az 1., 2. és 3. 
számú leletegyüttes a pliocén „Csarnótai” biosztratigráfiai egységhez sorolható, míg a 4. számú fauna valamivel fiatalabb (már pleisztocén) korú (SzENTESI et al. 2015). Ökológiailag egy nedves, erdős környezet után egy szárazabb, füves, nyílt növényzetú élőhely megjelenését tanúsítják az állatok maradványai.

Csarnótához hasonlóan a legjelentôsebb pliocén lelőhelyek — Beremend és Osztramos — leginkább „határ-képződményeknek" tekinthetők. Klasszikus értelemben véve ugyanis nem lelőhelyek, hanem inkább lelőhelycsoportok, amelyek számos karsztüregükben különbözô, a pliocéntől a pleisztocén idősebb szakaszaiig korolható faunákat tartalmaznak. Példaképpen az osztramosi mészkőbányát szeretnénk részletesebben bemutatni.

Az Osztramos (vagy más néven Esztramos) hegy, a Rudabányai-hegység legészakibb jelentős tagja, Tornaszentandrás és Bódvarákó között emelkedik. Fő tömegét triász, ladin korú, világos színú Wettersteini Mészkő alkotja, a Bódva felőli meredek letörésének alján pedig alsó-anisusi Gutensteini Dolomit és Mészkő van. Az Osztramoson a középkortól az 1950-es évek elejéig hematit, sziderit és okker, majd kohászati adalékanyagként mészkő bányászat volt, és eközben kerültek feltárásra, majd nagyrészt megszúntek a gerinces maradványokat szolgáltató hasadékok és barlangok (JÁNOSSY \& KORDOS 1977).

$\mathrm{Az}$ Osztramos őslénytani feltárásai fooként JÁNOSSY Dénes vezetésével folytak 1967 és 1973 között, amelyek eredményeként 14, a kora pliocéntől a középsô pleisztocénig (4,2-1,0 millió év) datált gerinces lelóhelyet azonosítottak. Noha ezen feltárások többségét késôbb a bányászati tevékenység elpusztította, az összegyújtött anyagot jelenleg a Magyar Természettudományi Múzeum és a Magyar Bányászati és Földtani Szolgálat gyújteményében őrzik.

Az 1, 4, 5, 7, 8, 10, 11, 12, 14-es lelőhelyek anyaga tektonikus hasadékkitöltésből, a 2, 3, 6, 9, 13-asé pedig különféle barlangkitöltésekből származik. Ezekből az üregekből Európában egyedülálló leletegyüttes került elő, amely korban igen széles skálát ölel fel, és rendkívüli újdonságokkal szolgált mind rendszertani szempontból (több tucat új taxon leírása), mind a rétegtan és a paleoökológia számára. Rétegtanilag szerencsésen egészíti ki a Villányi-hegység hasonló korú klasszikus sorozatát, és földrajzilag éppen annyira tér el attól, hogy összevetésükkel a klímaváltozások regionális különbségeit is tanulmányozni lehessen.

Az egyes lelőhelyeket a következő korokba lehetett sorolni: középsô-pliocén (1, 10-es lelőhely); plio-pleisztocén határ (7-es lelőhely); alsó-pleisztocén (3, 6, 11-es lelőhely); alsó-pleisztocén vége $(2,8,12,14$-es lelőhely), középsőpleisztocén (4, 5, 12/a lelőhely).

A rendkívül gazdag kétéltű, hüllő, rovarevő, denevér, rágcsáló, nyúlalakú, ragadozó és patás faunáról a legteljesebb áttekintést JÁNOSSY \& KORDOS (1977) nyújtotta, de az egyes rendszertani csoportokról azóta is számos részletes taxonómiai tanulmány született (pl. GoDAWA 1993; HíR 1996; REUMER 1984; TOPÁL 1989; VENCZEL 1997, 2001).

A beremendi Szőlő-hegy pliocén-pleisztocén gerinces faunáit a 19. század közepe óta ismerik. A maradványokat először PETÉnYi Salamon János írta le 1864-ben. Később összesen 26 helyet fedeztek fel, amelyeket a környezó mészkó folyamatos kitermelése miatt elpusztítottak. Több helyről származó tudományos anyag azonban innen is a Magyar Természettudományi Múzeum és a Magyar Bányászati és Földtani Szolgálat gyújteményébe került. A legfontosabb ásatásokat itt is JÁNOSSY Dénes vezette. A beremendi lelóhelyek revíziója napjainkban is zajlik (pl. PAZONYI et al. 2016).

\section{Negyedidöszak}

Pleisztocén faunák olyan gazdagságban kerültek elő a Kárpát-medencéből, hogy bemutatásuk önmagában nagyobb terjedelmet igényelne, mint az összes idősebb lelőhely együttvéve. Maradéktalan leírásukra ezért itt nem vállalkozhatunk, de ez talán nem is szükséges, mert a témát tudományos (JÁNOSSY 1979) és ismeretterjesztố (GASPARIK \& MEDZIHRADSZKY 2016) monográfiák kiválóan feldolgozták. Csak néhány olyan lelőhelyet szeretnénk példaként megemlíteni, amelyek jól reprezentálják a faunák páratlan gazdagságát és nemzetközi jelentőségét. Jelentőségüket bizonyítja, hogy a Kárpát-medence pleisztocén faunáira alapuló biokronológiai egységeket (Villányium, Biharium), valamint a KRETZOI Miklós és JÁNOSSY Dénes által bevezetett faunaszinteket a nemzetközi szakirodalom is használja (KRETZOI \& PÉCSI 1982).

A felvidéki pleisztocén lelőhelyek közül feltétlenül meg kell említenünk a Gombaszög (Gombasek) barlang- és egyéb karsztüreg-kitöltéseiból 1930 óta, több periódusban feltárt gazdag kis- és nagyemlős faunát (GASPARIK \& WAGNER 2014).

Erdélyből az 1900-as évek elején felfedezett betfiai lelőhely szolgáltatta a legjelentősebb negyedidőszaki faunaegyüttest. Az elmúlt több mint 100 év ásatásai eredményeképpen a betfiai lelőhelyek száma 14-re emelkedett. Az azonosított kétéltứ, hüllő-, madár- és emlősfajok mennyisége megközelíti a kétszázat, közülük több tucatot innen írtak le először. A páratlan faunáról már eddig is taxonómiai szakcikkek hosszú sora jelent meg, de a lelőhelyek kiaknázása és fosszilis faunáinak teljes feldolgozása még távolról sem tekinthető befejezettnek. A kilencvenes évek elejétől például Venczel Márton és HíR János a IX. számú lelőhelyen végzett jelentôs anyaggyújtést (VENCZEL 1998). Betfia a Bihari emelet típuslelőhelye.

A magyarországi pleisztocénból JÁNOSSY Dénes (1979) monográfiája több mint 100 lelőhelyet sorol fel. Ez legalább másfélszer ennyi faunát jelent, hiszen némelyik lelőhelyen több különböző korú és ökológiai összetételú közösséget lehetett azonosítani. A maradványok kisebb hányada folyóvízi vagy eolikus üledékekből származik, legnagyobb részük azonban karsztos üregek (barlangok, hasadékok, kôfülkék) üledékkitöltéseiből került elő. A középsô-pleisztocéntől a Kárpát-medencében is uralkodóvá váló ,jégkori faunák" a negyedidőszaki éghajlat glaciális és interglaciális állapotait, valamint a kisebb klímaingadozásokat egyaránt jól tükrözik. Ez részben a tipikus jégkorszaki nagyemlősök (mamut, gyapjas orrszarvú, barlangi medve, barlangi hiéna, barlangi oroszlán, rénszarvas stb.) megjelenésével vagy 
visszaszorulásával mutatható ki. De a klíma- és ökoszisztéma-rekonstrukciókban ennél is nagyobb szerepet játszik a statisztikus mennyiségben megjelenő kisemlős (denevér, rovarevő, rágcsáló) fauna összetétele (3. ábra $D, F)$. A paleoökológiai változásokról több korszerú, átfogó munka is készült (pl. PAZONYI 2004).

A kora-pleisztocén villányi korszakot a szárazabbá váló klímán és nyíltabb vegetációjú területeken a pockok (Arvicolinae) evolúciós robbanása kísérte. Ebben az időszakban még sok pliocén reliktum faj élt, de már számos új elem is megjelent a faunában. Így a háromujjú ôslovak (Hipparion) mellett feltúntek az egyujjú lovak (Equus), a kardfogúak (Machairodontidae) melett megjelentek az ősoroszlánok (Panthera). Új bevándorló volt például a déli mamut (Mammuthus meridionalis), vagy a valódi medvék (Ursus) és a farkasok (Canis) első képviselői. A kora-bihari idején a glaciális időszakok jelentősebb lehúlést okoztak, és a sztyeppek még nagyobb területen terjedtek el. A gyökeres fogú pockok visszaszorultak, és ettól kezdve dominálnak a gyökértelen fogú formák. Sok reliktum faj eltûnésével, a ma élő genusok többségének megjelenésével és a már itt élők elterjedésével „modern fauna” alakult ki.

A középső-pleisztocénben a megmaradt harmadidőszaki reliktum fajok (a ma is élő kevés kivételtôl eltekintve) eltûntek a faunából, és a meglevő genusokon (Panthera, Canis, Ursus, Bison, Capreolus, Cervus, Mammuthus, Sorex, Arvicola, Microtus, Lagopus) belül kialakult új fajokkal jellegzetes ,,jégkori” élővilágot figyelhetünk meg.

A késô-pleisztocén klímaingadozásait a rendelkezésünkre álló nagy mennyiségú adat alapján viszonylag pontosan ismerjük. A KoRDOs (1992) által kidolgozott módszerrel 10 jellemző pocok-és lemmingfaj dominanciaviszonyai alapján a hazai késô-pleisztocénre részletes biosztratigráfiai tagolás adható. A klímarekonstrukciók és a korbesorolás elkészítésénél más kisemlőscsoportok (pl. hörcsögök, cickányok, denevérek) fajösszetételét is felhasználhatjuk. A legjellegzetesebb nagyemlősfajok ebből az időszakból: gyapjas mamut (Mammuthus primigenius), gyapjas orrszarvú (Coelodonta antiquitatis), sztyeppi bölény (Bison priscus), őstulok (Bos promigenius), modern ôslovak és vadszamár (Equus fajok), barlangi medve (Ursus spelaeus), barlangi hiéna (Crocuta crocuta spelaea), barlangi oroszlán (Panthera leo spelaea), rénszarvas (Rangifer tarandus), óriásszarvas (Megaloceros giganteus) stb. (GASPARIK \& MEDZIHRADSZKY 2016).

Az ősi emberfélék leletei is előkerültek számos helyről. A Gerecse déli lábánál fekvő Vértesszőlős határában a középsô-pleisztocén édesvízi mészkő a Homo heidelbergensis 250-300 ezer éves maradványait őrizte meg számunkra. A Homo erectusból Európában kifejlődött faj legismertebb hazai lelete az 1965-ben felfedezett, Sámuel névre keresztelt nyakszirtcsont (os occipitale). Az 1960-as években VÉRTES László ősrégész vezetésével végzett ásatások gazdag, viszonylag enyhe klímát jelző növény- és állatvilágot tártak fel. Ezek tanúsága szerint a mészkövet felhalmozó forrás közelében dúsabb, nedvességkedvelő közösség élt, távolabb pedig nagyobb erdőfoltokkal tarkított sztyepp terült el (KRETZOI \& DoBosi 1990).
A Cserépfalutól északra, a Bükk mészkövében (Hórvölgy) nyíló Subalyuk üledékéből a neandervölgyi ember (Homo neanderthalensis) több csontját tárták fel a kutatások, amelyeket elsősorban DANCZA János és KADIĆ Ottokár irányított. A lelőhelyen sok állati csontot is találtak, amelyek arra utalnak, hogy az ősemberek egy hidegebb periódus idején éltek itt, mintegy 60 ezer éve (BARTUCZ et al. 1938).

A mai ember (Homo sapiens sapiens) leletei számos barlangból előkerültek (VÉRTES 1965). Az istállóskői (Bükk hegység) leletek azt bizonyítják, hogy közvetlen őseink már 35 ezer évvel ezelőtt - európai bevándorlásukkal egy időben - megjelentek a Kárpát-medencében (PATOU-MATHIS et al. 2016).

JÁNOSSY (1979) részletesen bemutatja és elemzi a hazai pleisztocén gerinces faunák összetételét. A monográfia megjelenése óta azonban több lelőhelyen is jelentôs kutatások folytak, amelyek eredményei még nem jelenhettek meg a könyvben. Ilyen volt például a Villányi-hegységben a Somssich-hegy (PAZONYI et al. 2018), a Gerecsében Süttó (PAZONYI et al. 2014) és Tokod (GASPARIK 1993), a Bükkben pedig a Vaskapu-barlang (VIRÁG et al. 2013, MÉSZÁROS 2013). Ezeken a lelőhelyeken a teljes faunára kiterjedő taxonómiai vizsgálatokat tafonómiai, geokémiai és egyéb korszerú elemzésekkel is kiegészítették.

A pleisztocén lelőhelyek egy részének teljes spektrumú kutatása tehát ma is zajlik. Mostanában azonban egyre inkább az egyes csoportok taxonómiai, filogenetikai és paleogeográfiai kapcsolatainak tisztázását célzó szakértői vizsgálatok kerülnek előtérbe. A gazdag gerinces anyagot őrzô gyűjtemények rendkívüli lehetőséget nyújtanak erre a hazai és a számos más országból érkező specialisták számára. A leletanyag taxonómiai jelentőségét támasztja alá például, hogy KoRdos \& PAZONYI (2012) monográfiája 60 olyan fajt vagy alfajt sorol fel a pleisztocén tagolásában kulcssszerepet játszó pocokfélék (Arvicolinae) közül, amelynek típuspéldányát a Kárpát-medencéből írták le.

A barlangkitöltések fiatalabb rétegeiből előkerült kisemlősfaunák lehetőséget nyújtottak a holocén időszak finomsztratigráfiai tagolásának elkészítéséhez (KoRDOs 1982) és jelentősen hozzájárultak a földtörténeti közelmúlt ökológiai változásainak felderítéséhez is (PAZONYI 2009).

\section{Hol érdemes még kutatni?}

A most összefoglaltak alapján tehát világosan látszik, hogy a magyarországi preneogén üledékes kőzetek, bár nem bővelkednek gerincesek fosszíliáiban, mindig van új a nap alatt, és tudatos, célzott kutatás révén értékelhető és őslénytani, földtani szempontból fontos gerinces leletanyagok fedezhetôk fel. Újabb oldási technikák, iszapolási eljárások és szisztematikus keresés révén olyan területeken is megtalálhatjuk, ha mást nem, mikrogerincesek fosszíliáit, ahol korábban ilyenek nem kerültek elő. Ezek között is van néhány olyan terület és földtani képződmény, melyek potenciálisak lehetnek jelentôsebb gerinces fosszíliák szempontjából is. 
Időrendi sorrendben haladva a Füle település határában található Fülei Konglomerátum Formáció felső-karbon homokkő-aleurolit rétegeit említhetjük elôször. A település határában található Kő-hegy kis kőfejtőiben évtizedekkel ezelőtt számos jó megtartású, makroszkopikus növénymaradvány került elő (MiHÁLY 1980), és mivel az ott látható rétegek folyóvízi körülmények között rakódtak le, van esély akár kétéltûek és hüllők leleteire is bukkanni.

A mezozoikumi rétegsorokat illetôen a Mecseki Karolina-völgy, felső-triász, karni homokkő rétegeit kell megemlíteni, melyek alapvetôen folyóvízi körülmények között rakódtak le. Ezek a rétegek a gerinces élővilág történetének azon periódusát reprezentálják, amikor a legkorábbi dinoszauruszok, krokodilok és repülő hüllők éltek. Bár a Karolina-völgy területén a feltárt rétegsor jelentős része igen kemény kőzetekből épül fel, kitartó munkával megvan az esély rá, hogy gerincesek fosszíliáira bukkanjunk.

A paleogén rétegeket illetően is volna még mit kutatni. Lábatlan határában a Bersek-hegy területén található a jól ismert és mára rendkívül alaposan tanulmányozott márgafejtő alsó-kréta korú rétegsora. A feltárás legfelsố részén diszkordánsan középső-eocén édesvízi kavics, homokkő és mészkő rétegek fedik a kréta időszaki rétegeket. Középsőeocén üledékes kőzetek viszonylag nagy területen fordulnak elő a Dunántúli-középhegység területén, ám ezek döntően brakkvízi-normálsósvízi körülmények között rakódtak le, és a transzgressziót megelőző édesvízi-brakkvízi, szenes rétegek vagy csak nagyon kis vastagságban, vagy mélyen a felszín alatt érhetốk el. Ezekből a rétegekből akár tengeri (pl. szirének), akár szeimaquatikus- szárazföldi (pl. krokodilok, növényevő és ragadozó emlősök) gerincesek további fosszíliáinak felfedezése nagyban hozzájárulhat a Dunántúli-középhegység utolsó nagy tengerelöntését megelőzően létezett gerines élővilág megismeréséhez.

A neogén és kvarter folyóvízi, mocsári és tavi üledékes kőzetek is rejthetnek újabb fosszilis anyagokat, valamint újabb karsztüregkitöltések is kerülhetnek elő, elsősorban a mészkőbányászat során. Ebből az időből azonban olyan nagy mennyiségú, begyújtött, de még feldolgozatlan anyag várakozik a gyưjjteményekben a szakértők munkájára, hogy várhatóan ezek laboratóriumi feldolgozása is jelentôs újdonságokkal szolgál majd.

\section{Konklúzió}

A Kárpát-medence területérôl ismert több száz millió évet átfogó gerinces őslénytani rekord és a leletanyagokat dokumentáló 150 évnyi publikációs tevékenység rendkívül fontos szerepet játszott Eurázsia és egyáltalán földünk gerinces élővilágának megismerésében. Különösen igaz ez az abban a viszonylatban, hogy a Kárpát-medencét alkotó kisebb-nagyobb szerkezeti egységek mozgalmas múltra tekintenek vissza, mely folyamatosan befolyásolta az egykori területeken kialakult környezetek változását. Ezekhez a változásokhoz az élővilág többi szereplőihez hasonlóan a gerincesek is alkalmazkodtak, és leleteik árulkodnak osállatföldrajzi kapcsolataikról is. A hazai gerinces leletek fontos szerepet játszanak a mezozoikumi Európa déli peremén élt tengeri faunák megismerésében, és meghatározóak a kréta időszaki európai szigetvilág négydimenziós faunafejlődésének megértésében. Szórványleletekkel hozzájárulnak a paleogén medencék tengeri emlőseinek és a medenceperemi szárazulatokon élő gerinces csoportok pontosabb megismeréséhez. A neogén és pleisztocén faunákat illetôen pedig, különösen a szárazföldi leletegyüttesek tekintetében, nagyhatalomnak számítunk a régióban: regionális korok, faunaszintek és új taxonok tucatjai kerültek leírásra a Kárpát-medencéből, melyek nem utolsósorban hírét vitték e leletanyagoknak és kutatóiknak szerte a nagyvilágban.

\section{Köszönetnyilvánítás}

Köszönjük MAGYAR Jánosnak (ELTE Dinoszaurusz Kutatócsoport) a kézirat szerkesztésében nyújtott segítségét. Hálásak vagyunk Főzy Istvánnak (Magyar Természettudományi Múzeum, Budapest), CsIKI-SAVA Zoltánnak (Bukarest Románia), Szabó Mártonnak (ELTE Dinoszaurusz Kutatócsoport, Budapest) és FuTó Jánosnak az ábrákhoz használt képanyag biztosításáért. Köszönjük VENCZEL Márton (Nagyvárad) és egy anonim bíráló értékes tanácsait a kézirattal kapcsolatban. A kutatást a NKFIH K 131597 számú projekt támogatta.

\section{Irodalom - References}

Angelone, C. \& Čermák, S. 2015: Two new species of Prolagus (Lagomorpha, Mammalia) from the Late Miocene of Hungary: taxonomy, biochronology, and palaeobiogeography. — Paläontologische Zeitschrift 89/4, 1023-1038. https://doi.org/10.1007/ s12542-014-0247-Z

BACHMAYER, F. \& SzYndLaR, Z. 1985: Ophidians (Reptilia: Serpentes) from the Kohfidisch fissures of Burgenland, Austria. — Annalen des Naturhistorischen Museums in Wien, Serie A 87, 79-100.

BARABÁSNÉ STUHL Á. 1975: Adatok a dunántúli újpaleozóos képződmények biosztratigráfiájához. — Földtani Közlöny 105, 320-334.

Bartucz L., Dancza J., Hollendonner F., Kadić O., Mottl M., Pataki V., Pálos E., Szabó J., Vendl A. 1938: A cserépfalui Mussolini-barlang (Subalyuk). - Geologica Hungarica, Series Palaeontologica 14, 320 p.

Begun, D. R. 2007: Fossil Record of Miocene Hominoids. — In: Henke, W., Rothe, H. \& Tattersall, I. (eds): Handbook of Palaeoanthropology Vol. 2.: Primate Evolution and Human Origins. — Springer, Berlin, 921-977.

BEGUN, D. R. 2020: 50 years of fossil catarrhines from Rudabanya: sympatry and social organization. — American Journal of Physical Anthropology 171/S69, p. 23. https://doi.org/10.1002/ajpa.24023 
Benton, M. J., Cook, E., Grigorescu, D., Popa, E. \& TAllodi, E. 1997: Dinosaurs and other tetrapods in an Early Cretaceous bauxitefilled fissure, northwestern Romania. - Palaeogeography, Palaeoclimatology, Palaeoecology 130/1-4, 275-292. https://doi.org/ 10.1016/S0031-0182(96)00151-4

Benton, M. J., Csiki, Z., Grigorescu, D., Redelstorff, R., Sander, P. M., Stein, K. \& Weishampel, D. B. 2010: Dinosaurs and the island rule: The dwarfed dinosaurs from Hațeg Island. — Palaeogeography, Palaeoclimatology, Palaeoecology 293, $438-454$. https://doi.org/10.1016/j.palaeo.2010.01.026

BernoR, R. L., Kaiser, T. M., Kordos, L. \& SCotT, R. S. 1999: Stratigraphic context, systematic position and paleoecology of Hippotherium sumegense Kretzoi, 1984 from MN 10 (Late Vallesian of the Pannonian Basin). — Mitteilung der Bayerischen Staatssammlung für Paläontologie und historische Geologie 39, 1-35.

Bernor, R. L., Mittmann, H. W., \& Rögl, F. 1991: Systematics and Chronology of the Götzendorf „Hipparion” (Late Miocene, Pannonian F, Vienna Basin). - Annalen des Naturhistorischen Museums in Wien, Serie A 95, 101-120

Bernor, R. L., Kordos, L., Rook, L., Agustí, J., Andrews, P., Armour-Chelu, M., Begun, D. R., Cameron, D. W., Damuth, J., Daxner-Höck, G., De Bonis, L., Fejfar, O., Fessaha, N., Fortelius, M., Franzen, J., Gasparik, M., Gentry, A., Heissig, K., Hernyak, N., Kaiser, T., Koufos, G. D., Krolopp, E., Jánossy, D., Llenas, M., Meszáros, L., Müller, P., Renne, P., Rocek, Z., Sen, S., Scott, R., Szyndlar, Z., Topál, Gy., Ungar, P. S., Utescher, T., Van Dam J. A., Werdelin, L. \& Ziegler, R. 2004: Recent advances on multidisciplinary research at Rudabánya, Late Miocene (MN9), Hungary: a compendium. — Palaeontographia Italica 89, 3-36.

BöcKH J. 1875: Brachydiastematherium transilvanicum, egy új Pachyderma nem Erdély eocén rétegeiből. — A Magyar Királyi Földtani Intézet Évkönyve 4, 1-21.

Bodor, E. R. \& BARANYAI, V. 2012: Palynomorphs of the Normapolles group and related plant meso fossils from the Iharkút vertebrate site, Bakony Mountains (Hungary). — Central European Geology 55, 259-292. https://doi.org/10.1556/CEuGeol.55.2012.3.3

BodoR E. R. \& MAKÁDI L. 2016: Triász szórványleletek az MFGI gyứjteményéből. — 19. Magyar Ốslénytani Vándorgyúlés. — Program, elöadáskivonatok, kirándulásvezetó, Kozárd, 8-9.

BonTó L. 2019: A mi kavicsfogúnk. Placochelys placodonta, a Veszprémben felfedezett kavicsfogú álteknős. — Veszprémi Szemle 21, 6-64.

Botfalvai, G., HaAs, J., Mindszenty, A. \& Ósi, A. 2016: Facies architecture and paleoenvironmental implications of the Upper Cretaceous (Santonian) Csehbánya Formation at the Iharkút vertebrate locality (Bakony Mountains, northwestern Hungary). Palaeogeography, Palaeoclimatology, Palaeoecology 441/4, 659-678. https://doi.org/10.1016/j.palaeo.2015.10.018

Botfalvai, G., ŐsI, A. \& MindsZENTY, A. 2015: Taphonomic and paleoecologic investigations of the Late Cretaceous (Santonian) Iharkút vertebrate assemblage (Bakony Mts, Northwestern Hungary). — Palaeogeography, Palaeoclimatology, Palaeoecology 417, 379_ 405. https://doi.org/10.1016/j.palaeo.2014.09.032

Botfalvai, G., Gyóri, O., Pozsgai, E., Farkas, I. M., SáGi, T. \& Szabó, M. 2019: Sedimentological characteristics and paleoenvironmental implication of Triassic vertebrate localities in Villány (Villány Hills, Southern Hungary). — Geologica Carpathica 70/2, 135-152. https://doi.org/10.2478/geoca-2019-0008

BöHM, B. 1941: Die Fossilen Fische von Kovászna und Kommandó in Siebenbürgen. — Mitteilungen aus dem Jahrbuch der Kgl. ungarischen Geologischen Anstalt 35, 179-203.

BöHM, B. 1942: Beiträge zur tertiären Fischfauna Ungarns: Adatok a magyarországi harmadkori halfaunához. — Geologica Hungarica, Series Palaeontologica 19, 3-42.

Brassói Fuchs H. 1994: Adatok a kolozsvári (Cluj, Románia) felsőeocénből leírt „Euclastes” kochi Lőrenthey, 1903 (Testudinata, Cheloniidae?) faj pontosabb ismeretéhez. — Földtani Közlöny 124/4, 479-482.

Ciobanu, R. 2002: Selacienii paleogeni din România. — Editura Universității Lucian Blaga, Sibiu, 216 p.

Codrea, V. 2000: Rinoceri i tapiri terțiari din România. —Editura Presa Universitarâ Clujeanâ, Cluj-Napoca, 174 p.

CSERPÁK F. 2018: Középső-miocén sziláscet (Cetacea: Mysticeti) humerusok a Pécs, danitzpusztai homokbányából. —Földtani Közlöny 148/3, 255-255. https://doi.org/10.23928/foldt.kozl.2018.148.3.255

CsiKI, Z. \& GRIGORESCU, D. 1998: Small theropods of the Late Cretaceous of the Hațeg Basin (Western Romania) — an unexpected diversity at the top of the food chain. - Oryctos 1, 87-104.

CSIKI, Z. \& GRIGORESCU, D. 2000: Teeth of multituberculate mammals from the Late Cretaceous of Romania. — Acta Palaeontologica Polonica 45, 85-90.

Csiki, Z., Codrea, V., Jipa-Murzea, C. \& Godefroit, P. 2010a: A partial titanosaur (Sauropoda, Dinosauria) skeleton from the Maastrichtian of Nălaț-Vad, Hațeg Basin, Romania. — Neues Jahrbuch für Geologie und Paläontologie Abhandlungen 258, 297324. https://doi.org/10.1127/0077-7749/2010/0098

Csiki, Z., Grigorescu, D, Codrea, V. \& Therrein, F. 2010b: Taphonomic modes in the Maastrichtian continental deposits of the Hațeg Basin, Romania.- Palaeoecological and palaeobiological inferences. - Palaeogeography, Palaeoclimatology, Palaeoecology 293/3-4, 375-390. https://doi.org/10.1016/j.palaeo.2009.10.013

CSiki, Z., VRemiR, M., Brusatte, S. L. \& Norell, M. A. 2010c: An aberrant island-dwelling theropod dinosaur from the Late Cretaceous of Romania. - Proceedings of the National Academy of Sciences 107, 15357-15361. https://doi.org/10.1073/pnas.1006970107

Csiki-Sava, Z., Buffateut, E., Ósi, A., Pereda-Suberbiola, X. \& Brusatte, S. L. 2015: Island life in the Cretaceous-faunal composition, biogeography, evolution, and extinction of land-living vertebrates on the Late Cretaceous European archipelago. ZooKeys 469, p. 1. https://doi.org/10.3897/zookeys.469.8439

DunAI M. 2012: Temnodontosaurus trigonodon lelet a gerecsei alsó jurából. — 15. Magyar Őslénytani Vándorgyúlés. — Program, elôadáskivonatok, kirándulásvezetô, Uzsa, p. 11.

DYKE, G. \& ŐsI, A. 2010: A review of Late Cretaceous fossil birds from Hungary. — Geological Journal 45, 434-444. https://doi.org/10.1002/ gj.1209 
Dyke, G. J., Benton, M. J., Posmosanu, E. \& Naish, D. 2011: Early Cretaceous (Berriasian) birds and pterosaurs from the Cornet bauxite mine, Romania. — Palaeontology 54/1, 79-95. https://doi.org/10.1111/j.1475-4983.2010.00997.x

Eastham, L. C., Feranec, R. S. \& Begun, D. R. 2016: Stable isotopes show resource partitioning among the early Late Miocene herbivore community at Rudabánya II: Paleoenvironmental implications for the hominoid, Rudapithecus hungaricus. Palaeogeography, Palaeoclimatology, Palaeoecology 454, 161-174. https://doi.org/10.1016/j.palaeo.2016.04.036

FeJfar, O., SABOL, M. \& TóTH, C. 2012: Early Pliocene vertebrates from Ivanovce and Hajnáčka (Slovakia). VIII. Ursidae, Mustelidae, Tapiridae, Bovidae and Proboscidea from Ivanovce. — Neues Jahrbuch für Geologie und Paläontologie-Abhandlungen 264/2, 95115 .

FenNinger, A. \& Nievoll, J. 1983: Der erste Nachweis einer phyllodonten Zahnplatte aus dem oberen Perm des Bükkgebirges (Ungarn). - Magyar Állami Földtani Intézet Évi Jelentése az 1981. évröl,201-207.

FốZY I. \& SZENTE I. 2007. A Kárpát-medence ösmaradványai. — Gondolat Kiadó, Budapest, 456 p.

Freudenthal, M. \& Kordos, L. 1989: Cricetus polgardiensis sp. nov. and Cricetus kormosi Schaub, 1930 from the Late Miocene Polgárdi localities (Hungary). - Scripta Geologica 89, 71-100.

FÜLÖP J. 1990: Magyarország geológiája. Paleozoikum I. — Magyar Állami Földtani Intézet, kiadványa, Budapest, 325 p.

GASPARIK, M. 1993: Late Pleistocene gastropod and vertebrate fauna from Tokod (NE Transdanubia, Hungary). - Fragmenta Mineralogica et Palaeontologia 16, 89-116.

GASPARIK, M. \& WAGNER, J. 2014: Research history of Pleistocene faunas in Gombasek quarry (Slovakia), with comments to the type specimen and the type locality of Ursus deningeri gombaszogensis Kretzoi, 1938. - Fragmenta Palaeontologica Hungarica 31, 125-143. https://doi.org/10.17111/FragmPalHung.2014.31.125

Gasparik M. \& MedZigradszzky Zs. 2016: A mi jégkorszakunk. Pleisztocén élóvilág a Kárpát-medencében. — Magyar Természettudományi Múzeum, Herman Ottó Intézet, Budapest, 208 p.

Gere, K., SCHEYER, T. M., MAKÁDI, L. \& ÔSI, A. in press: Placodont remains (Sauropsida, Sauropterygia) from the Triassic of Hungary (Transdanubian Range and Villány Mountains). — Palaeobiodiversity and Palaeoenvironments.

GodAwA, J. 1993: Pliocene bats of the genus Myotis (Mammalia: Chiroptera) from Podlesice (Poland) and Osztramos 9 and 13 (Hungary). - Acta Zoologica Cracoviensia 36/2, 241-250.

Grigorescu, D. \& Hahn, G. 1987: The first multituberculate teeth from the Upper Cretaceous of Europe (Romania). — Geologica et Palaeontologica 21, 237-241.

Grigorescu, D., Hartenberger, J. L., Rădulescu, C., SAmson, P. \& Suder, J. 1985: Découverte de mam-mifčres et dinosaures dans le Crétacé supérieur de Pui (Roumanie). — Comptes Rendus de l'Académie des Sciences. Série 2, Mécanique, Physique, Chimie, Sciences de l'univers, Sciences de la Terre 301, 1365-1368.

Grigorescu, D., ŞeClăman, M., Norman, D. B. \& Weishampel, D. B. 1990: Dinosaur eggs from Romania. — Nature 346/6283, p. 417. https://doi.org/10.1038/346417a0

Grigorescu, D., Garcia, G., Csiki, Z., Codrea, V. \& Bojar, A. V. 2010: Uppermost Cretaceous megaloolithid eggs from the Hațeg Basin, Romania, associated with hadrosaur hatchlings: Search for explanation. - Palaeogeography, Palaeoclimatology, Palaeoecology 293, 360-374. https://doi.org/10.1016/j.palaeo.2010.03.031

Gunz, P., Kozakowski, S., Neubauer, S., Le Cabec, A., Kullmer, O., Benazzi, S., Hublin J. J. \& Begun, D. R. 2020: Skull reconstruction of the late Miocene ape Rudapithecus hungaricus from Rudabánya, Hungary. — Journal of Human Evolution 138, 102687. https://doi.org/10.1016/j.jhevol.2019.102687

Hips K., JozSA S., NAGY Á. \& PATAKI Zs. 1988: Őshüllők nyomában. — Természet Világa 120, 108-111.

Hír, J. 1996: Cricetinus janossyi sp. n. (Rodentia, Mammalia) from the Pliocene fauna of Osztramos 7. (N Hungary). — Fragmenta Mineralogica et Palaeontologica 18, 79-90.

Hír, J. 2006: Late Astaracian (Late Sarmatian) Lagomorphs and Rodents from Felsőtárkány-Felnémet (Northern Hungary). — Beiträge zur Paläontologie 30, 155-173.

Hír, J. \& MÉszÁros, L. Gy. 2002: Middle Miocene insectivores and rodents (Mammalia) from Sámsonháza (Northern Hungary). — Fragmenta Palaeontologica Hungarica 20, 9-23.

HuZA, R. R., JurCSÁK, T. \& TALLÓDI, E. 1987: Fauna de reptile triasice din Bihor. — Crisia 17, 571-578.

JAEKel, O. 1902: Ueber Placochelys n.g. und ihre Bedeutung für die Stammesgeschichte der Schildkröten. — Neues Jahrbuch für Mineralogie, Geologie und Paläontologie 1, 127-144.

JAEKEL, O. 1907: Placochelys placodonta aus der Obertrias des Bakony. — In: LócZY, L. (ed.): Resultate der wissenschaftlichen Erforschung des Balatonsees. I. Band. Physische Geographie des Balatonsees und seiner Umgebung. 1. Theil. Geographische Beschreibung der Balatonsee-Umgebung, sammt deren Orographie und Geologie. Paläontologische Anhang, 1-90. Budapest: Balatonsee-Commission der Ungarischen geographischen Gesellschaft.

JÁNOSSY D. 1979: A magyarországi pleisztocén tagolása gerinces faunák alapján. — Akadémiai Kiadó, Budapest, 207 p.

JÁNossY D. \& KoRdos J. 1977: Az Osztramos gerinces lelőhelyeinek faunisztikai és karsztmorfológiai áttekintése. — Fragmenta Minerologica et Palaeontologica 8, 39-72.

JURCSÁK, T. 1973: Date noi asupra reptilelor mezozoice din Transilvania. — Nymphaea 1, 245-261.

JuRCSÁK, T. 1975: Tanystropheus biharicus n. sp., une nouvelle éspece pour la faune triasique de Roumanie. — Nymphaea, Oradea 3, 45-52. JURCSÁK, T. 1976: Noi descoperiri de reptile fosile în triasicul de la Aleşd. — Nymphaea 4, 67-105.

JURCSÁK, T. 1977: Contributii noi privind placodontele şi sauropterigienii din triasicul de la Aleşd (Bihor, România). — Nymphaea 5, 530.

JURCSÁK, T. 1978: Rezultate noi în studiul saurienilor fosili de la Aleşd. — Nymphaea 6, 15-60.

JURCSÁK, T. 1982: Occurences nouvelles des sauriens mésozoique de Roumanie. — Vertebrata Hungarica 21, 175-185. 
JuRCSÁK, T. 1988: Triassic reptilian fauna from Bihor, Romania. — In: CurRIE, P. M. \& Koster, E. H. (eds): Fourth symposium on mesosoic terrestrial ecosystems. — Drumheller, 125-128.

JURCSÁK, T. \& KESSLER, R. 1986: Evolutia avifaunei pe teritorul României. I. —Nymphaea 16, 577-615.

JuRCSÁK, T. \& Kessler, R. 1987: Evolutia avifaunei pe territorul României. II. Morfologia speciilor fosile. — Nymphaea 17, 583-609.

JuRCSÁK, T. \& KeSSLER, R. 1991: The Lower Cretaceous paleofauna from Cornet, Bihor County, Romania. — Nymphaea 21, 5-32.

JURCSÁK, T. \& POPA, E. 1978: Resturi de dinozaurieni în bauxitele de la Cornet (Bihor). — Nymphaea 6, 61-64.

JuRCSÁK, T. \& PoPA, E. 1979: Dinozaurieni ornitopozi din bauxitele de la Cornet (Muntii Padurea Craiului). — Nymphaea 7, 37-75.

Jurcsák, T. \& PopA, E. 1983: La faune de dinosauriens du Bihor (Roumanie). — In: Buffetaut, E., Mazin, J. M. \& SALMON, E. (eds): Actes du Symposium paléontologique G. Cuvier, Montbéliard. — Ville de Montbéliard, Paris, 325-388.

Jurcsák, T. \& Popa, E. 1984: Pterosaurians from the Cretaceous of Cornet, Roumania. — In: ReIF, W. E. \& WestPHAL, F. (eds): Third symposium on Mesozoic terrestrial ecosystems, short papers. - Attempto, Tübingen, $259 \mathrm{p}$.

KADIĆ O. 1915: A Szeleta barlang kutatásának eredményei. — A Földtani Intézet Évkönyve 23, 151-278.

KAdIĆ O. \& KoRmos T. 1934: A hámori Puskaporos és faunája Borsodmegyében. - A Magyar Állami Földtani Intézet Évkönyve 19/3, $117-163$.

Kadić O. \& MotTl M. 1944: Az északnyugati Bükk barlangjai. — Barlangkutatás 17, 1-84.

KASZAP A. 1968: Korynichium spaerodactylum (Pabst) a balatonrendesi permben. — Földtani Közlöny 98/3-4, 429-433.

KatONA, L. T., KUTASI, C., PAPP, B. \& TÓTH, S. 2014: Further remarkable palaeontological finds at the alginite quarry in Pula. — Annales historico-naturales Musei nationalis hungarici 106, 117-140.

KaZÁR, E. 2005: A new kentriodontid (Cetacea: Delphinoidea) from the middle Miocene of Hungary. — Mitteilungen aus dem Museum für Naturkunde in Berlin, Geowissenschaftliche Reihe 8, 53-73. https://doi.org/10.1002/mmng.200410004

KAZÁR, E. 2006: Odontocete periotics (Mammalia: Cetacea) from the Carpathian Basin, Middle Miocene (Badenian and Sarmatian Stages), including the Vienna Basin, Austria. — Beiträge zur Paläontologie 30, 269-292.

KazÁr E., Kordos L. \& Szónoky M. 2007: Danitz-puszta. — In: PÁlfy J. \& PAzonyi P. (szerk.): Őslénytani kirándulások Magyarországon és Erdélyben. — Hantken Kiadó, Budapest, 131-132.

Kessler, E. 1984: Lower Cretaceous birds from Cornet (Romania). — In: ReIF, W. E. \& WestPhal, F. (eds): Third symposium on Mesozoic terrestrial ecosystems, short papers. — Attempto, Tübingen, $259 \mathrm{p}$.

Kessler, E. \& JuRCsÁK, K. T. 1984a: Fossil bird remains in the bauxite from Cornet (Padurea Craiului Mountains — Romania). — 75 Years Laboratory of Paleontology Special Volume. University of Bucharest, 129-134.

Kessler, E. \& JurCsÁK, K. T. 1984b: Fossil bird remains in the bauxite from Cornet (Romania, Bihor county). — Travaux du Muséum d'Histoire naturelle Grigore Antipa 25, 393-401.

KESSLER, E. \& JURCSÁK, K. T 1986: New contributions to the knowledge of Lower Cretaceous bird remains from Cornet (Romania). Travaux du Muséum d'Histoire naturelle Grigore Antipa 28, 289-295.

Koch A. 1900: A Magyar Korona Országai kövült gerincesállat maradványainak rendszeres átnézete. — Magyar Orvosok és Természetvizsgálók Vándorgyúléseinek Munkálatai 30,526-560.

Косн A. 1903: Tarnócz Nógrád megyében, mint kövült czápafogaknak új gazdag lelőhelye. — Földtani Közlöny 33, $22-44$.

Kocsis, L. 2002: Middle Eocene Hyrachyus cf. stehlini (Mammalia, Perissodactyla) from the Gerecse Hills, Hungary. — Neues Jahrbuch für Geologie und Paläontologie, Monatshefte 11, 649-658. https://doi.org/10.1127/njgpm/2002/2002/649

Kocsis, L. 2007: Central paratethyan shark fauna (Ipolytarnóc, Hungary). — Geologica Carpathica 58/1, 27-40.

Kocsis L. 2016: Újabb eredmények az ipolytarnóci cápafogas rétegről, illetve annak faunájáról. — In: GuBA S. \& SzARVAS I. (szerk.): Ősmaradványok nyomában: Ipolytarnóc földtani megismerése I. — Bükki Nemzeti Park Igazgatóság, Eger, 53-76.

Kocsis, L., Vennemann, T. W., Hegner, E., Fontignie, D. \& TütKen, T. 2009: Constraints on Miocene oceanography and climate in the Western and Central Paratethys: O-, Sr-, and Nd-isotope compositions of marine fish and mammal remains. - Palaeogeography, Palaeoclimatology, Palaeoecology 271, 117-129. https://doi.org/10.1016/j.palaeo.2008.10.003

KoRDOS L. 1977: Új felsőeocén sziréna (Paralitherium tarkanyense n.g. n.sp.) Felsôtárkányból (A New Upper Eocene Sirenian (Paralitherium tarkanyense n.g. n.sp.) from Felsőtárkány, NE Hungary.) — Magyar Állami Földtani Intézet Évi Jelentése 1977, 349-367.

KoRDOs L. 1978: Magyarország eocén, oligocén és miocén ősgerinces lelőhelyei. — Magyar Állami Földtani Intézet Évi Jelentése az 1976. évról, 291-295.

KoRDos L. 1981: Újabb sárkánygyík lábnyom Komlóról. —Élet és Tudomány 25, 796.

KORDOS, L. 1982: Evolution of the Holocene vertebrate fauna in the Carpathian Basin. — Zeitschrift für geologische Wissenschaften 10/7, 963-970.

KORDOs L. 1983: Fontosabb szórványleletek a MÁFI gerinces-gyưjteményében (8. közlemény). Dinosaurus lábnyomok (Komlosaurus carbonis n. g. n. sp.) a mecseki liaszból. — Magyar Állami Földtani Intézet Évi Jelentése az 1981. évról, 503-511.

KoRDOS, L. 1985a: Footprints in the Lower Miocene sandstone of Ipolytarnóc. - Geologica Hungarica, Series Palaeontologica 46, 257-415.

KoRdOS, L. 1985b: Lower Turolian (Neogene) Anomalospalax gen. n. from Hungary and its phylogenetic position. - Fragmenta Mineralogica et Palaeontologica 12, 27-42.

KoRDOS L. 1986: A hasznosi és szentendrei felső-miocén hörcsögök (Cricetidae, Mammalia) rendszertani és rétegani vizsgálata. Magyar Állami Földtani Intézet Évi Jelentése az, 1984. évról, 523-553.

KoRDOS, L. 1987: Karstocricetus skofleki gen. n., sp. n. and the evolution of the Late Neogene Cricetidae in the Carpathian Basin. Fragmenta Mineralogica et Palaeontologica 13, 65-88.

Kordos L. 1989: Dinoszaurusz-lelet a Mecsekben. — Tudomány 5/2, 17-18.

KoRDOS L. 1992: Magyarország harmad- és negyedidőszaki emlősfaunájának fejlődése és biokronológiája. — Kézirat, Akadémiai doktori értekezés, Budapest, 104 p. 
KoRDOS, L. 1997: Environmental and Hominoid History in the Carpathian Basin During late Miocene. — In: Climatic and Environmental Change in the Neogene of Europe. - ESF Workshop, Siena, 13-14.

KoRdos L. 2003: Baltavár és a felső-miocén globális környezetváltozás. — 6. Magyar Őslénytani Vándorgyúlés. — Program, kirándulásvezetố, elöadáskivonatok, Zirc, p. 19.

KoRdOs L. 2005: Őshüllők lábnyomai a Mecsekben. —-In: FAZEKAS I. (szerk.): A komlói térség természeti és kultúrtörténeti öröksége. Regiografo Bt. Komló, 75-90.

KordOS L. 2015: Rudapithecus hungaricus: Egy nemzeti érték ötven éve. — Magyar Tudomány 10, 1226-1235.

KoRDos L. 2018: Misztikus ősállatnyomok a Balaton körül. — Természet Világa 149, 242-245.

KoRdos, L. \& Begun, D. R. 2001: A new cranium of Dryopithecus from Rudabánya, Hungary. — Journal of Human Evolution 41/6, 689700. https://doi.org/10.1006/jhev.2001.0523

KoRdos L. \& Solt P. 1984: A magyarországi miocén tengeri gerinces faunaszintek vázlata. — Magyar Állami Földtani Intézet Évi Jelentése az 1982. évról, 347-354.

Kordos L. \& PAZONYI P. 2012: A magyar Arvicolinae típusok katalógusa. Catalogue of the Hungarian Arvicolinae Types. - SZTE TTIK Földrajzi és Földtani Tanszékcsoport, Szeged, 105 p.

Kormos T. 1911: A Polgárdi pliocén csontlelet. — Földtani Közlöny 41/1, 48-64.

Kormos T. 1914: Az 1913. évben végzett ásatásaim eredményei. — Magyar Állami Földtani Intézet Évi Jelentése az, 1913. évról, $506-523$.

Kormos T. 1917: Az ajnácskői pliocén rétegek és faunájuk. — Magyar Állami Földtani Intézet Évi Jelentése az 1915. évról, $582-654$.

Kormos T. 1925: A süttői forrásmészkő-komplexum faunája. - Állattani Közlemények 22/3-4, 159-175.

Kormos, T. 1937: Zur Frage der Abstammung und Herkunft der qurtären Säugetier-Fauna Europas. — Festschr. 60. Geburstage v. Prof. Dr. Embrik Strand 3, 287-328.

Kovács, J., Németh, K., Szabó, P., Kocsis, L., Kereszturi, G., ÚjVÁri, G. \& Vennemann, T. 2020: Volcanism and paleoenvironment of the Pula maar complex: A pliocene terrestrial fossil site in Central Europe (Hungary). — Palaeogeography, Palaeoclimatology, Palaeoecology 537, 109398. https://doi.org/10.1016/j.palaeo.2019.109398

KozUR, H. 1984: New biostratigraphical data from the Bükk, Uppony, and Mecsek Mts., and their tectonical implications. — Acta Geologica Hungarica 27/3-4, 307-319.

Kozur, H. \& Mock, R. 1977: On the age of the Paleozoic of the Uppony Mountains (North Hungary). — Acta Mineralogica et Petrographica 23/1, 91-107.

KretzoI, M. 1940: Alttertiäre Perissodactylen aus Ungarn. — Annales Musei nationali hungarici 33, 87-97.

KRETZOI M. 1941: Ósemlősmaradványok Betfiáról. — Földtani Közlöny 71, 235-261.

KRETZOI M. 1943: Kochictis centennii n. g. n. sp. az egeresi felső oligocénből. — Földtani Közlöny 73/1-3, 10-17.

KRETZOI M. 1954: Befejező jelentés a Csákvári barlang őslénytani feltárásáról. — Magyar Állami Földtani Intézet Évi Jelentése az, 1952. évról, 37-69.

KreTzor M. 1955: A hazai emlôsállatok fejlődéstörténete. Útmutató a TIT elóadói számára. — Társadalom- és Természettudományi Ismeretterjesztő Társulat, Budapest, 23 p.

KRETZoi M. 1956a: A Bodajk-kajmáti kőfejtố katti faunája. — Kézirat, Magyar Bányászati és Földtani Szolgálat Adattára.

KRETZOI M. 1956b: A Villányi hegység alsó-pleisztocén gerinces-faunái. — Geologica Hungarica, Series Palaeontologica $27,1-264$.

KRETZOI M. 1962: A csarnótai fauna és faunaszint. — Magyar Állami Földtani Intézet Évi Jelentése az 1959. évról, 297-343.

Kretzor M. 1984: A Sümeg-gerinci fauna és faunaszakasz. — Geologica Hungarica, Series Geologica 20, 214-222.

KretzoI, M. 2002: The Fossil Hominoids of Rudabánya (Northeastern Hungary) and Early Hominization. — Hungarian National Museum, Budapest, $287 \mathrm{p}$.

Kretzor, M., \& Dobosi, V. T. (eds.) 1990: Vértesszólôs: Site, man and culture. — Akadémiai Kiadó, Budapest, 555 p.

KRETZOI M. \& NosZKY J. 1951: Saurius-fog a bakonyi bauxitképződményből. — Földtani Közlöny 81, p. 333.

KRETZOI M. \& PÉCSI M. 1982: A Pannóniai-medence pliocén és pleisztocén időszakának tagolása. — Földrajzi Közlemények 30/4, 300-326.

LELKES-FelVÁRI Gy., KovÁCS S. \& MAJOROS Gy. 1984: Alsó-devon pelágikus mészkő a Kékkút 4. sz. fúrásban (Lower Devonian pelagic limestone in borehole Kékkút-4, Bakony Mts.). — Annual Report of the Hungarian Geological Institute 1982, 289-315.

LŐRENTHEY I. 1903: Két új teknősfaj a kolozsvári eocén képződményekből. — Földtani Közlöny 23/5-6, 193-208.

LŐRENTHEY I. 1907: Vannak-e juraidőszaki rétegek Budapesten? — Földtani Közlöny 37, 359-368.

MAKÁDI, L. 2006: Bicuspidon aff. hatzegiensis (Squamata: Scincomorpha: Teiidae) from the Upper Cretaceous Csehbánya Formation (Hungary, Bakony Mts). — Acta Geologica Hungarica 49, 373-385. https://dx.doi.org/10.1556/AGeol.49.2006.4.5

MAKÁDI, L. 2013a: A new polyglyphanodontine lizard (Squamata: Borioteiioidea) from the Late Cretaceous Iharkút locality (Santonian, Hungary). — Cretaceous Research 46, 166-176. https://doi.org/10.1016/j.cretres.2013.08.001

MAKÁDI, L. 2013b: The first known chamopsiid lizard (Squamata) from the Upper Cretaceous of Europe (Csehbánya Formation; Hungary, Bakony Mts). — Annales de Paléontologie 99, 261-274. https://doi.org/10.1016/j.annpal.2013.07.002

MAKÁDI, L., CALDWELL, M. W. \& ŐsI, A. 2012: The first freshwater mosasauroid (Upper Cretaceous, Hungary) and a new clade of basal mosasauroids. — PLOS ONE 7/12, e51781. https://doi.org/10.1371/journal.pone.0051781

Makádi L., Botfalvai G., Galambos Cs., Magyar J., Szabó M. \& Ősi A. 2019: Alsó-kréta (albai) kontinentális gerincesek a Bakonyból. —22. Magyar Ôslénytani Vándorgyưlés. —Program, elóadáskivonatok, kirándulásvezetó, Döbrönte, 25-26.

MAJOROS Gy. 1964: Ốshüllő-lábnyom a balatonrendesi permből. — Földtani Közlöny 94/2, 243-245.

Marchetti, L., Tessarollo, A., Felletti, F. \& Ronchi, A. 2017: Tetrapod footprint paleoecology: behavior, taphonomy and ichnofauna disentangled. a case study from the Lower Permian of the Southern Alps (Italy). — Palaios 32/8, 506-527. https://doi.org/10.2110/ palo. 2016.108

MARINESCU, F. 1989: Lentila de bauxita 204 de la Brusturi Cornet (Jud. Bihor), zacam nt fosilifer cu dinozauri. — Ocrotirea Naturii si a Mediuului Inconjurator, Academia Română 33, 125-133. 
MÉszÁros, L. Gy. 1997: Kordosia, a new genus for some Late Miocene Amblycoptini shrews (Mammalia, Insectivora). — Neues Jahrbuch für Geologie und Paläontologie, Monatshefte 1997/2, 65-78. https://doi.org/10.1127/njgpm/1997/1997/65

MÉszÁros, L. Gy. 1998: Late Miocene Soricidae (Mammalia) fauna from Tardosbánya (Western Hungary). — Hantkeniana 2, 103-125.

MÉszÁros, L. Gy. 1999a: An exceptionally rich Soricidae (Mammalia) fauna from the upper Miocene localities of Polgárdi (Hungary). - Annales Universitatis Scientiarum Budapestinensis de Rolando Eötvös nominatae Sectio Geologica 32, 5-34.

MÉszÁros, L. Gy. 1999b: Some insectivore (Mammalia) remains from the Late Miocene locality of Alsótelekes (Hungary). — Annales Universitatis Scientiarum Budapestinensis de Rolando Eötvös nominatae Sectio Geologica 32, 35-47.

MÉszáros, L. 2013: Review of the Late Pleistocene Soricidae (Mammalia) fauna of the Vaskapu Cave (North Hungary). — Hantkeniana 8, 163-169.

MiHÁLY S. 1980: Felső-karbon növénymaradványok a fülei Kő-hegyről. — Veszprém Megyei Múzeumok Közleményei 15, 21-28.

NopCSA, F. 1902: Dinosaurierreste aus Siebenbürgen (Schädelreste von Mochlodon mit einem Anhange: Zur Phylogenie der Ornithopodiden). Mit einem Anhange: Zur Phylogenie der Ornithopodiden. — Denkschriften der Kaiserlichen Akademie der Wissenschaften, Mathematisch-Naturwissenschaftliche Klasse 72, 149-175.

NopCSA, F. 1915: Die Dinosaurier der Siebenbürgischen Landesteile Ungarns. — Mitteilungen aus dem Jahrbuch der Ungarischen Geologischen Reichsanstalt 23, 1-24.

NoPCSA, F. 1929: Dinosaurierreste aus Siebenbürgen V. — Geologica Hungarica, Series Palaeontologica 4, 1-76.

ORAVECZ J. 1964: Szilur képződmények Magyarországon. — Földtani Közlöny 94/1, 3-9.

Ősı A. 2001: Középső-eocén teknősleletek Nyíres-pusztáról (Déli-Bakony) — Földtani Közlöny 131/3-4,353-360.

Ósı, A. 2005: Hungarosaurus tormai, a new ankylosaur (Dinosauria) from the Upper Cretaceous of Hungary. - Journal of Vertebrate Paleontology 25, 370-383. https://doi.org/10.1671/0272-4634(2005)025[0370:htanad]2.0.co;2

ÖsI, A. 2008: Enantiornithine bird remains from the Late Cretaceous of Hungary. - Oryctos 7, 55-60.

Ősı A. 2012: A kavicsfogú álteknős, Laczkó Dezső leghíresebb őslénytani lelete. — Természet Világa 143/4, 180-183.

Ósi A., BARACKA M. \& Szente I. 2005a: Dino-ösvény: kora-jura dinoszaurusz lábnyomok a Mecsekból. — Hantken Press, Budapest, 31 p.

ÖsI, A., Weishampel, D. B. \& Jianu, C. M. 2005b: First evidence of azhdarchid pterosaurs from the Late Cretaceous of Hungary. — Acta Palaeontologica Polonica 50/4, 777-787.

Ősi, A., Clark, J. M. \& Weishampel, D. B. 2007: First report on a new basal eusuchian crocodyliform with multicusped teeth from the Upper Cretaceous (Santonian) of Hungary. - Neues Jahrbuch für Geologie und Paläontologie Abhandlungen 243, 169-177. https://doi.org/10.1127/0077-7749/2007/0243-0169

Ösi, A., Apesteguía, S. \& Kowalewski, M. 2010a: Non-avian theropod dinosaurs from the early Late Cretaceous of Central Europe. Cretaceous Research 31/3, 304-320. https://doi.org/10.1016/j.cretres.2010.01.001

ÓsI, A., ButLer, R. J. \& WeIshamPel, D. B. 2010b: A Late Cretaceous ceratopsian dinosaur from Europe with Asian affinities. — Nature 465/7297, 466-468. https://doi.org/10.1038/nature09019

Ősi, A., Buffetaut, E. \& Prondvai, E. 2011a: New pterosaurian remains from the Late Cretaceous (Santonian) of Hungary (Iharkút, Csehbánya Formation). — Cretaceous Research 32/4, 456-463. https://doi.org/10.1016/j.cretres.2011.01.011

Ősi, A., PÁlfy, J., MAKÁdi, L., Szentesi, Z., Gulyás, P., Rabi, M., Botfalvai, G. \& HiPs, K. 2011b: Hettangian (Early Jurassic) Dinosaur Tracksites from the Mecsek Mountains, Hungary. — Ichnos 18/2, 79-94. https://doi.org/10.1080/10420940.2011.573603

ÔSI, A., RABI, M., MAKÁDI, L., SZEnTESI, Z., BotFalVAI, G. \& GulYÁs, P. 2012: The Late Cretaceous continental vertebrate fauna from Iharkút (western Hungary, Central Europe): a review. - In: Godefroit, P. (ed.): Bernissart dinosaurs and Early Cretaceous terrestrial ecosystems. - Indiana University Press, Bloomington, 532-569.

Ősi, A., Pozsgai, E., Botfalvai, G., Götz, A. E., Prondvai, E., Makádi, L., Hajdu, Zs., Csengődi, D., Cziruák, G., Sebe, K. \& Szentesi, Z. 2013: First report of Triassic vertebrate assemblages from the Villány Hills (Southern Hungary). — Central European Geology 56/4, 297-335. https://doi.org/10.1556/CEuGeol.56.2013.4.2

ÔSI, A., RABI, M. \& MAKÁDI, L. 2015: An enigmatic crocodyliform tooth from the bauxites of western Hungary suggests hidden mesoeucrocodylian diversity in the Early Cretaceous European archipelago. — PeerJ 3, e1160. https://doi.org/10.7717/peerj.1160

ŐsI, A., Bodor, E. R., MAKÁDI, L. \& RABI, M. 2016: Vertebrate remains from the Upper Cretaceous (Santonian) Ajka Coal formation, western hungary. —Cretaceous Research 57, 228-238. https://doi.org/10.1016/j.cretres.2015.04.014

Ósı, A., Young, M. T., Galácz, A. \& RABI, M. 2018: A new large-bodied thalattosuchian crocodyliform from the Lower Jurassic (Toarcian) of Hungary, with further evidence of the mosaic acquisition of marine adaptations in Metriorhynchoidea. - PeerJ 6, e4668. https://doi.org/10.7717/peerj.4668

Ósi, A., Botfalvai, G., Albert, G. \& Hajdu, Zs. 2019: The dirty dozen: taxonomical and taphonomical overview of a unique ankylosaurian (Dinosauria: Ornithischia) assemblage from the Santonian Iharkút locality, Hungary. — Palaeobiodiversity and Palaeoenvironments 99/2, 195-240. https://doi.org/10.1007/s12549-018-0362-z

Ősı, A., SzaBó, M. \& BotfalvaI, G. 2020: Tanystropheus and other archosauromorph reptile remains from the Middle and Late Triassic of Villány (Villány Hills, Hungary). — Geologica Carpatica 71/3, 264-273.

PÁlfy, J., Mundil, R., Renne, P. R., Bernor, R. L., Kordos, L. \& GASPARIK, M. 2007: U-Pb and 40Ar/39Ar dating of the Miocene fossil track site at Ipolytarnóc (Hungary) and its implications. - Earth and Planetary Science Letters 258/1-2, 160-174. https://doi.org/10.1016/j.epsl.2007.03.029

Patrulius, D., Marinescu, F. \& Balters, A. 1983: Dinosauriens ornithopodes dans les bauxites Nèocomiennes de l'Unitéde Bihor (Monts Apuseni). — Anuarul Institutului de Geologie si Geofizica 59, 109-117.

PAUCĂ, M. 1934: Über die fossile Fischgattung Mrazecia Paucă. — Notationes Biologicae 2/3, 90-91.

PAZONYI, P. 2004: Mammalian ecosystem dynamics in the Carpathian Basin during the last 27,000 years. - Palaeogeography, Palaeoclimatology, Palaeoecology 212/3-4, 295-314. https://doi.org/10.1016/j.palaeo.2004.06.008 
PAZONYI P. 2009: A Kárpát-medence felső-pliocén és kvarter emlősfauna közösségeinek paleoökológiai vizsgálata. — Földtani Közlöny 139/3, 283-304.

Pazonyi, P., Kordos, L., Magyari, E., Marinova, E., FǘőH, L. \& Venczel, M. 2014: Pleistocene vertebrate faunas of the Süttó travertine complex (Hungary). — Quaternary International 319, 50-63. https://doi.org/10.1016/j.quaint.2013.02.031

PAZONYI, P., MÉsZÁRos, L., Hír, J. \& SZENTESI, Z. 2016: Pleistocene rodent and soricid (Mammalia) fauna from The lowermost Beremend 14 locality (South Hungary) and its biostratigraphical and palaeoecological implications. — Fragmenta Palaeontologica Hungarica 33, 99-134. https://doi.org/10.17111/FragmPalHung.2016.33.99

Pazonyi, P., ViráG, A., Gere, K., Botfalvai, G., Sebe, K., Szentesi, Z., Mészáros, L., Botka, D., Gasparik, M. \& Korecz, L. 2018: Sedimentological, taphonomical and palaeoecological aspects of the late early Pleistocene vertebrate fauna from the Somssich Hill 2 site (South Hungary). — Comptes Rendus Palevol 17/4-5, 296-309. https://doi.org/10.1016/j.crpv.2017.06. 007

Patou-Mathis, M., Vercoutère, C., Lengyel, G., Szolyák, P. \& Mester, Z. 2016: New interpretation of the upper Palaeolithic human occupations at the Istállóskő cave (Bükk Mountains, Hungary). — Eurasian Prehistory 13/1-2, 77-90.

Popa, E., Tallódi, E., HuZa, R. R. \& Mazin, J. M. 1996: Les sites Triasiques de Peştiş et de Lugaş, Bihor, Roumanie. Historique et perspecives. - Nymphaea 22, 43-51.

Posmosanu, E. 2003a: Iguanodontian dinosaurs from the lower Cretaceous Bauxite site from Romania. — Acta Palaeontologica Romaniae 4, 431-439.

Posmosanu, E. 2003b: Revision of the Early Cretaceous dinosaur (Ornithopoda) collection from the bauxite deposit lens 204 — Cornet, Romania. - Nymphaea 30, 25-38.

Posmosanu, E. 2003c: New data on Lower Cretaceous dinosaurs from Romania. —European Association of Vertebrate Palaeontologists, 1st Meeting, Abstract of Papers and Posters, Basel, $49 \mathrm{p}$.

Posmosanu, E. \& CooK, E. 2000: Vertebrate taphonomy and dinosaur palaeopathology from a Lower Cretaceous bauxite lens, North West Romania. - Oryctos 3, 39-51.

Prieto, J., van den Hoek Ostende, L. W., Hír, J. \& Kordos, L. 2015: The Middle Miocene insectivores from Hasznos (Hungary, Nógrád County). - Palaeobiodiversity and Palaeoenvironments 95/3, 431-451. https://doi.org/10.1007/s12549-015-0193-0

Prondvai, E., Botfalvai, G., Stein, K., Szentesi, Z. \& Ősi, A. 2017: Collection of the thinnest: A unique eggshell assemblage from the Late Cretaceous vertebrate locality of Iharkút (Hungary). — Central European Geology 60/1, 73-133. https://doi.org/10.1556/ 24.60.2017.004

Rabi, M. \& Botfalvai, G. 2008: A preliminary report on the Late Oligocene vertebrate fauna from Máriahalom, Hungary. — Hantkeniana 6, 177-185.

RABI, M. \& SEBôK, N. 2015: A revised Eurogondwana model: Late Cretaceous notosuchian crocodyliforms and other vertebrate taxa suggest the retention of episodic faunal links between Europe and Gondwana during most of the Cretaceous. — Gondwana Research 28/3, 1197-1211. https://doi.org/10.1016/j.gr.2014.09.015

Rabi, M., Tong, H. \& Botfalvai, G. 2012: A new species of the side-necked turtle Foxemys (Pelome-dusoides: Bothremydidae) from the Late Cretaceous of Hungary and the historical biogeography of the Bothremydini. — Geological Magazine 149, 662-674. https://doi.org/ 10.1017/S0016756811000756

Rabi, M., Bastl, K., Botfalvai, G., Evanics, Z. \& Peigné, S. 2018: A new carnivoran fauna from the late Oligocene of Hungary. Palaeobiodiversity and Palaeoenvironments 98/3, 509-521. https://doi.org/10.1007/s12549-017-0308-x

RÁlisch-Felgenhauer E. 1981: Templomhegyi Dolomit Formáció (Templomhegy Dolomite Formation). — MÁFI Jelentés villányihegységi alapszelvények vizsgálatáról (Geological Institute of Hungary report about the study of key sections of the Villány Hills). MÁFI, Budapest, $40 \mathrm{p}$.

Reumer, J. W. F. 1984: Ruscinian and early Pleistocene Soricidae (Insectivora, Mammalia) from Tegelen (The Netherlands) and Hungary. - Scripta Geologica 73, 1-173.

RIEPPEL, O. 2001: Cranial anatomy of Placochelys placodonta Jaekel, 1902, and a review of the Cyamodontoidea (Reptilia, Placodonta). — Fieldiana: Geology, New Series 45, 1-104. https://doi.org/10.5962/bhl.title.3449

SсHосH, R. R. 2014: Amphibian Evolution: The Life of Early Land Vertebrates. - Wiley, New York, 280 p.

SEGESDI, M. \& ÓSI, A.: Sauropterygian remains from the Middle Triassic of Villány, Hungary — new information on the aquatic reptile fauna of Tisza Megaunit (Triassic southern Eurasian shelf region). — Submitted to Paleodiversity and Paleoenvironments.

Segesdi, M., Botfalvai, G., Bodor, E. R., Ôsi, A., Buczkó, K., Dallos, Zs., ToKai, R. \& Földes, T. 2017: First report on vertebrate coprolites from the Upper Cretaceous (Santonian) Csehbánya Formation of Iharkút, Hungary. — Cretaceous Research 74, 87-99. https://doi.org/10.1016/j.cretres.2017.02.010

Solt, P. 1988: Odontaspis (Synodontaspis) divergens n. sp. from the Oligocene of Csillaghegy. — A Magyar Állami Földtani Intézet Évi Jelentése az 1986-os évról, 519-533.

SuEs, H. D. 2019: The Rise of Reptiles: 320 Million Years of Evolution. — Johns Hopkins University Press, Baltimore, 385 p.

SzABÓ, M. 2020: A Late Jurassic (Kimmeridgian-early Tithonian) fish fauna of the Eperkés-hegy (Olaszfalu, Bakony Mts., Hungary): the oldest record of Notidanodon Cappetta, 1975 and a short revision of Mesozoic Hexanchidae. — Palaeobiodiversity and Palaeoenvironments 100, 151-170. https://doi.org/10.1007/s12549-018-00368-x

SzABó, M. \& Ốsi, A. 2017: The continental fish fauna of the Late Cretaceous (Santonian) Iharkút locality (Bakony Mountains, Hungary). - Central European Geology 60/2, 230-287. https://doi.org/10.1556/24.60.2017.009

SZABÓ, M. \& PÁLFY, J. 2020: Dapedium sp. from the Toarcian (Lower Jurassic) Úrkút Manganese Ore Formation (Bakony Mts., Hungary) and an overview of diversity of dapediiform fishes. — Palaeobiodiversity and Palaeoenvironments 100, 179-195. https://doi.org/ $10.1007 / \mathrm{s} 12549-019-00390-7$ 
SzABÓ, M., GulYÁs, P. \& Ôsı, A. 2016a: Late Cretaceous (Santonian) pycnodontid (Actinopterygii, Pycnodontidae) remains from the freshwater deposits of the Csehbánya Formation, (Iharkút, Bakony Mountains, Hungary). — Annales de Paléontologie 102/2, 123_ 134. Elsevier Masson. https://doi.org/10.1016/j.annpal.2016.04.001

Szabó, M., GulYás, P. \& Ốsı, A. 2016b: Late Cretaceous (Santonian) Atractosteus (Actinopterygii, Lepisosteidae) remains from Hungary (Iharkút, Bakony Mountains). —Cretaceous Research 60, 239-252. https://doi.org/10.1016/j.cretres.2015.12.002

Szabó, M., Botfalvai, G., Kocsis, L., Carnevale, G., Sztanó, O., Evanics, Z. \& Rabi, M. 2017: Upper Oligocene marine fishes from nearshore deposits of the Central Paratethys (Máriahalom, Hungary). — Palaeobiodiversity and Palaeoenvironments 97/4, 747-771. https://doi.org/10.1007/s12549-017-0285-0

Szabó, M., Botfalvai, G. \& ÔSI, A. 2019: Taxonomical and palaeoecological investigations of the chondrichthyan and osteichthyan fish remains from the Middle-Late Triassic deposits of the Villány Hills (Southern Hungary). — Geobios 57, 111-126. https://doi.org/ 10.1016/j.geobios.2019.10.006

Szentesi, Z. \& Venczel, M. 2010: An advanced anuran from the Late Cretaceous (Santonian) of Hungary. — Neues Jahrbuch für Geologie und Paläontologie, Abhandlungen 256, 291-302. https://doi.org/10.1127/0077-7749/2010/0054

SZENTESI, Z. \& VENCZEL, M. 2012: A new discoglossid frog from the late Cretaceous (Santonian) of Hungary. — Cretaceous Research 34, 327-333. https://doi.org/10.1016/j.cretres.2011.11.012

SzENTESI, Z., GaRdNER, J. D. \& VencZel, M. 2013: Albanerpetontid amphibians from the Late Cretaceous (Santonian) of Iharkút, Hungary, with remarks on regional differences in Late Cretaceous Laurasian amphibian assemblages. — Canadian Journal of Earth Sciences 50, 268-281. https://doi.org/10.1139/e2012-024

SZENTESI, Z., PAZONYI, P. \& MÉsZÁros, L. 2015: Albanerpetontidae from the late Pliocene (MN 16A) Csarnóta 3 locality (Villány Hills, South Hungary) in the collection of the Hungarian Natural History Museum. — Fragmenta Palaeontologica Hungarica 32, 49-66. http://dx.doi.org/10.17111/FragmPalHung.2015.32.49

TASNÁDI-KUBACSKA A. 1967: Dinoszaurusz lábnyomok hazánkban. —Élet és Tudomány 24, 1118-1121.

TopáL, Gy. 1989: Tertiary and Early Quaternary remains of Corynorhinus and Plecotus from Hungary (Mammalia, Chiroptera). Vertebrata Hungarica 23, 33-55.

Vass, D., KonecnÝ, V., Tunyi, I., DolinskÝ, P., Balogh, K., HudÁcková, N., Kovácová-SlámkovÁ, M. \& BelÁceK, B. 2000: Origin of the Pliocene vertebrate bone accumulation at Hajnácka, southern Slovakia. - Geologica Carpathica 51/2, 69-82.

VENCZEL, M. 1997: Amphibians and reptiles from the lower Pleistocene of Osztramos (Hungary). — Nymphaea 23, 77-88

VENCZEL M. 1998: Gerinces ősmaradványok kutatása Biharban. —Állattani Közlemények 83, 129-134.

VencZel, M. 2001: Anurans and squamates from the Lower Pliocene (MN 14) Osztramos 1 locality (Northern Hungary). — Fragmenta Palaeontologica Hungaricca 19, 79-90.

Venczel, M. \& CodreA, V. A. 2019: A new Theriosuchus-like crocodyliform from the Maastrichtian of Romania. - Cretaceous Research 100, 24-38. https://doi.org/10.1016/j.cretres.2019.03.018

Venczel M. \& HíR J. 2008: Középső-miocén gerincesfaunák Partiumból. — Földtani Közlöny 138/4, 339-344.

Venczel, M. \& HíR, J. 2013: Amphibians and squamates from the Miocene of Felsőtárkány Basin, N Hungary. — Palaeontographica, Abteilung A 300, 117-158. https://doi.org/10.1127/pala/300/2013/117

VÉRTES L. 1965: Az ốskor és az átmeneti kókor emlékei Magyarországon. — Akadémiai Kiadó, Budapest, 385 p.

VirÁG, A., Szentesi, Z., CsÉFÁn, T. \& Kellner, L. M. 2013: The Late Pleistocene microvertebrate fauna of the Vaskapu Cave (North Hungary) and its taphonomical, biostratigraphical and palaeoecological implications. - Hantkeniana 8, 151-161.

VREMIR, M. 2004: Fossil turtle found in Romania-overview. — A Magyar Állami Földtani Intézet Évi Jelentése 2002, 143-152.

VREMIR, M. \& CoDREA, V. 1996: Palaeochelys sp. (Testudines; Emydidae) from the Paleocene of the Transylvanian depression: outcrops from Rona and Jibou (Salaj country, Romania). - Studii si Certetari (St. Naturii) 2, 75-81.

Vremir, M., Kellner, A. W. A., Naish, D. \& Dyke, G. J. 2013: A new azhdarchid pterosaur from the Late Cretaceous of the Transylvanian Basin, Romania: implications for azhdarchid diversity and distribution. - PLoS ONE 8/1, e54268. https://doi.org/10.1371/journal.pone.0054268

Vremir, M., Witton, M., Naish, D., Dyke, G., Brusatte, S. L., Norell, M. \& Totoianu, R. 2015: A medium-sized robust-necked azhdarchid pterosaur (Pterodactyloidea: Azhdarchidae) from the Maastrichtian of Pui (Hateg Basin, Transylvania, Romania). American Museum Novitates 3827, 1-16. https://doi.org/10.1206/3827.1

VoIGT, S. 2005: Die tetrapoden ichnofauna des kontinentalen oberkarbon und perm im thüringer Wald-ichnotaxonomie, paläoökologie und biostratigraphie. — PhD thesis, Martin-Luther-Universität Halle-Wittenberg, Cuvillier Verlag Göttingen, 308 p.

WeILER, W. 1933: Zwei oligozäne Fischfaunen aus dem Königreich ungarn. — Geologica Hungarica, Series Paleontologica 11, 1-54.

Weishampel, D. B., Grigorescu, D. \& Norman, D. B. 1991: The dinosaurs of Transylvania. — National Geographic Research \& Exploration 7/2, 196-215.

Weishampel, D. B., Jianu, C. M., Csiki, Z. \& Norman, D. B. 2003: Osteology and phylogeny of Zalmoxes (n.g.), an unusual euornithopod dinosaur from the latest Cretaceous of Romania. - Journal of Systematic Palaeontology 1, 65-123. https://doi.org/ $10.1017 / \mathrm{S} 1477201903001032$

Kézirat beérkezett: 2020. 05. 31 